\title{
Sustainable Building Plan-Design, Construction, Performance, and Renovation Criteria
}

\author{
Puthearath Chan ${ }^{1,2,3, *}$, Khemony Khoeng ${ }^{4}$, Hang Kheang Ung, ${ }^{4}$ Teksim Tang ${ }^{4}$, Kimsong Eung ${ }^{4}$, Suysoklin Uth ${ }^{5}$, \\ Sovanrany Meng', Leng Sun ${ }^{4}$, Sereyphut Em ${ }^{4}$, Hon Toum ${ }^{4}$, Oudomkitya Phok ${ }^{4}$, Ratha Sry ${ }^{4}$ Limdavid Mok ${ }^{4}$, \\ Rothvisal Lo ${ }^{4}$, Chanmakara Vat ${ }^{4}$, Sunleng Phay ${ }^{6}$, Otdom Hor ${ }^{4}$, Chey Vithyea Cheath ${ }^{4}$, Mengheang Lim ${ }^{4}$, \\ Pichbormey An", Mardy Sareun ${ }^{4}$, Sothet Sot ${ }^{6}$, Sievminh Va ${ }^{4}$, Yiheang Chea ${ }^{4}$, and Molly Ratana Piseth ${ }^{6}$
}

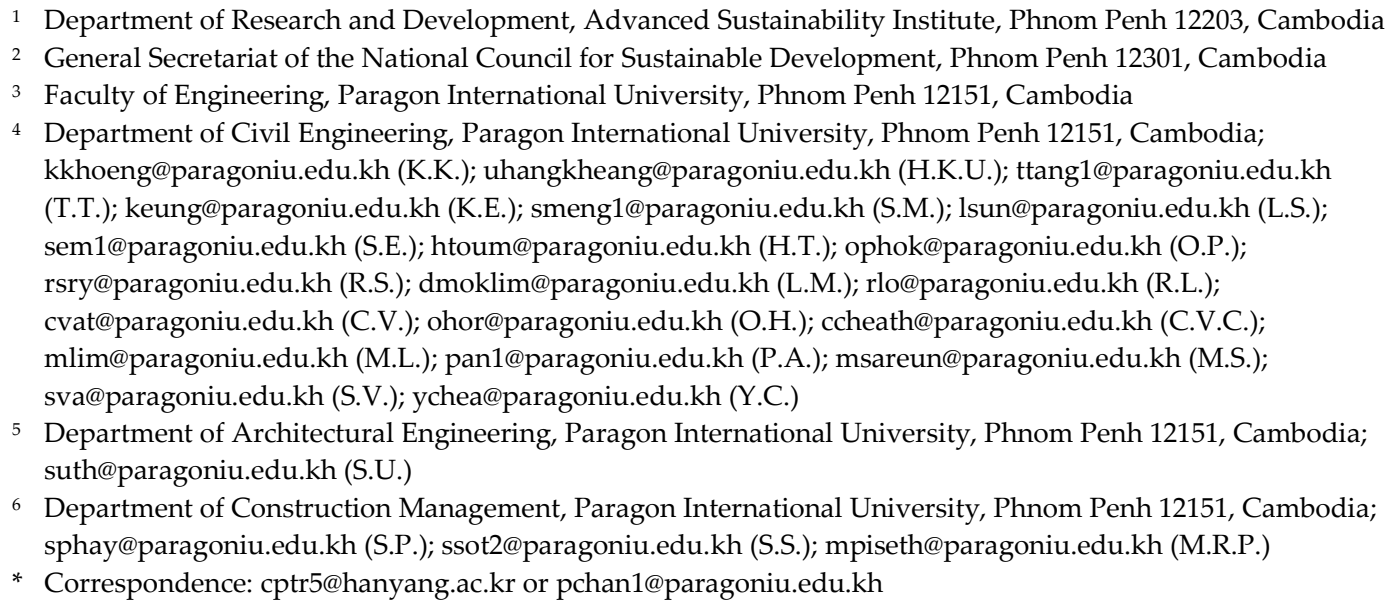

5 Department of Architectural Engineering, Paragon International University, Phnom Penh 12151, Cambodia; suth@paragoniu.edu.kh (S.U.)

6 Department of Construction Management, Paragon International University, Phnom Penh 12151, Cambodia; sphay@paragoniu.edu.kh (S.P.); ssot2@paragoniu.edu.kh (S.S.); mpiseth@paragoniu.edu.kh (M.R.P.)

* Correspondence: cptr5@hanyang.ac.kr or pchan1@paragoniu.edu.kh

\begin{abstract}
Published data or available literature on sustainable building plan-design, construction, performance, and renovation criteria have covered some stages or some parts of each stage. These data usually have been published partially in many different papers-there have not been any paper that published these data together. Hence, this paper aims to collectively review these data and publish them together. The collection and review of these data were carried out by our twenty-five team members who specialized in sustainable urban, architectural, and civil engineering and construction management. The gathered and reviewed outputs were combined and validated based on a general group consensus. This consensus decision-making proceeded through two major group meetings with several follow-up meetings. The first major meeting was to combine and improve the gathered reviewed sustainable building criteria for Cambodia. The second major meeting was to validate the improved reviewed sustainable building criteria for Cambodia. The several follow-up meetings were to discuss the relevance and importance of the validated data "criteria and their classifications and descriptions" in all stages and more focused on their importance and applicability to Cambodia. The collective reviewed data in this paper would be useful to researchers in the fields. They could also be useful collective knowledge and information for policymakers from governmental agencies and development partners, particularly for sustainable building and construction companies.
\end{abstract}

Keywords: sustainability; sustainable building criteria; sustainable building planning and design; sustainable site selection; sustainable construction; performance and renovation criteria.

\section{Introduction}

Buildings generally have impacts on environments and human health and their impacts have been seen clearly in cities [1]. According to the study of De Munck and her colleagues, increasing the use of air conditioning systems for cooling inside the buildings is generally releasing the waste heat into the atmosphere [2]. For example, the waste heat from air conditioners at night can raise urban temperature by more than $1^{\circ} \mathrm{C}[1,3]$. The buildings were also found significantly contributing to urban heat island (UHI) effects, making the city center getting hotter than its surrounding areas [4]. 
Cities generally have limited green and opened spaces, which is difficult to plant more trees and construct more urban gardens or water parks to reduce urban heat and environmental impacts. Therefore, the planning and design aiming to construct new buildings and to renovate existing low-performance buildings in a sustainable way are the greater solutions to reduce environmental impacts and heats in cities. Although the concept of sustainable buildings has been used worldwide, still how to apply this concept is quite challenging because every country has different contexts and development priorities, especially between developed and developing countries [5].

Cambodia, a developing country in Asia, is also facing these challenges while its building construction is rapidly growing. The construction is currently one of the key development sectors, and thousands of buildings in the main cities, such as Phnom Penh and Sihanoukville, are operating and being built [6]. However, most building construction have not been considered to include sustainability concepts while the building sector was found to be the most significant final energy consumer in Cambodia, with an estimated share of about 52 percent [7]. Energy consumption in the buildings will more than double until 2040 [6]. Therefore, promoting sustainable buildings in Cambodia is necessary for saving energy and reducing environmental impacts.

By recognizing the importance of sustainable buildings and realizing that buildings should be planned and designed based on sustainability concepts, Cambodia's National Council for Sustainable Development and its Secretariat through the Department of Green Economy is implementing a sustainable building guideline and certification project, funded by the Mekong-South Korean Cooperation Fund [6]. This guideline and certification project will develop assessment criteria based on and adapted from United States LEED, German DGNB, Vietnamese LOTUS, and Excellence in Design for Greater Efficiencies (EDGE) of the World Bank International Finance Corporation (IFC) [8].

Developing sustainable building criteria is not an easy task while there has been no research examined and discussed these criteria in Cambodia, even on the above-mentioned sources of criteria. This also shows a missed contribution from scientific research to sustainable building criteria development in Cambodia whereas there have been a lot of research conducted in many countries around the world. Lacking of scientific research and discussion is sometimes missed important inputs for developing such criteria because research usually provides comprehensive data and information and verifies the contexts related to topics, which is very important and useful to the government committee and policy makers, as a baseline or evidence, to support decision-making.

Hence, this study will collectively review the existing relevant sustainable building criteria for Cambodia. Then, this study will validate these data "collectively reviewed criteria" by using a general group consensus method for all sustainable building planning, design, construction, performance, and renovation stages and publish them together. These data would be useful to researchers in the fields. They could also be useful collective knowledge and information for policymakers from governmental agencies and development partners, particularly for sustainable building and construction companies.

\section{Methods}

Reviewing literature is important to summarize and report the relevant existing literature on the factors that influence the research topic [9]. Conducting a research based on existing knowledge is also addressed as building block of all academic research activities, regardless of discipline $[10,11]$. Recently, various papers have applied consensus methods to obtain accurate information and define areas where there is considerable uncertainty or a lack of agreed knowledge, as well as handle complex problems that require more judgmental analysis [12-16]. Accordingly, this paper validated the gathered and reviewed output data of sustainable building plan-design, construction, performance, and renovation criteria based on a general group consensus. This consensus decision-making proceeded through two major group meetings with several follow-up meetings. The first major meeting was to combine and improve the gathered/reviewed sustainable building criteria for Cambodia. The second major meeting was to validate the improved reviewed sustainable 
building criteria for Cambodia. The several follow-up meetings were to discuss the relevance and importance of the validated criteria and their classifications and descriptions" in all stages and more focused on their importance and applicability to Cambodia. The summary of data collection and validation (criteria validation) is shown in Figure 1.

The data collection and review were carried out by our twenty-five team members who specialized in relevant fields, such as sustainable urban, architectural, and civil engineering and construction management. The reviewed outputs were mostly sourced from existing relevant research literature available in Google Scholar whereas sustainable building planning and design criteria, sustainable building construction criteria, sustainable building performance criteria (or sustainable building operation and maintenance criteria), and sustainable building renovation criteria were among the search keywords. Additional sources were also used to support, reflect, and confirm the reviewed outputs. Those sources are comprehensive sustainable and green building guidebooks, such as "Home Remodeling: Green Building Guidelines" [17] and "Green Building Guide: Design Techniques, Construction Practices, and Materials for Affordable Housing" [18]. As shown in the figure below, the research methods have four major steps:

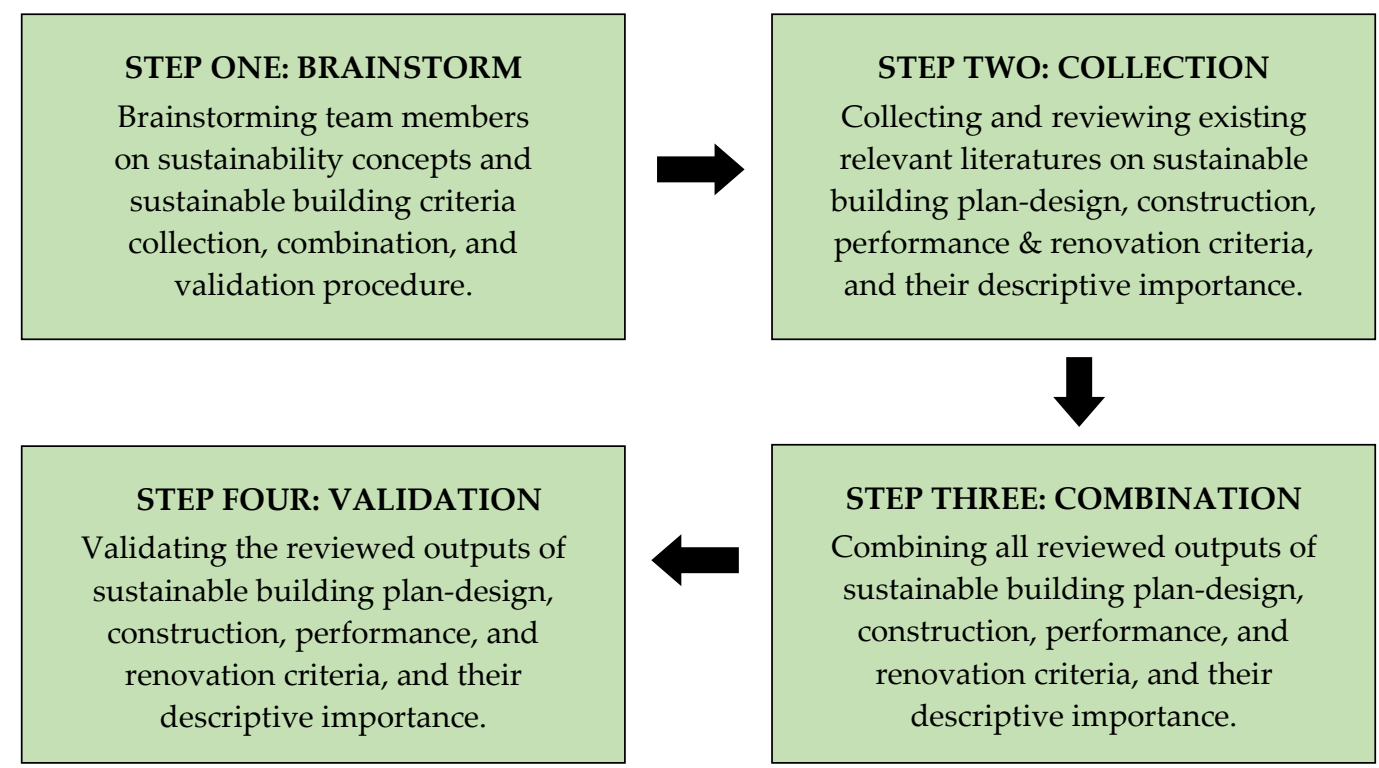

Figure 1. Summary of data collection and validation (criterial validation).

Brainstorming the team members on sustainability concepts and on sustainable building plan-design, construction, performance, and renovation criteria was the first step of this research. All the team members were brainstormed based on two comprehensive guidebooks $[17,18]$. Then, the team members were asked to preliminarily review the plandesign, construction, performance, and renovation criteria for sustainable buildings as practice. More importantly, all members fully conducted the review in the second step. A total number of eight, seven, five, and five members were responsible for each stage, plandesign, construction, performance, and renovation, respectively. Moreover, the reviewed outputs were combined in the third step. The combined outputs were finally validated by re-checking, improving, and selecting based on a general group consensus of the twentyfive team members. This consensus decision-making proceeded through two major group meetings with several follow-up meetings. The first major meeting was to combine and improve the gathered/reviewed sustainable building criteria for Cambodia. The second major meeting was to validate the improved reviewed sustainable building criteria for Cambodia. The several follow-up meetings were to discuss the relevance and importance of the validated criteria and their classifications and descriptions" in all sustainable building plan-design, construction, performance, and renovation stages and more focused on their importance and applicability to Cambodia. 


\section{Data Description}

Sustainable building plan-design criteria are needed to monitor and assess buildings towards becoming sustainable buildings. The sustainable building plan-design criteria are very important to guide a sustainable building project and its progress to meet the sustainable building requirements during the plan-design stage. Based on the validated output data (validated criteria) demonstrated in Table A1, the sustainable building plan-design criteria, including their classifications and their descriptive importance, are various and covered on many aspects, and based on the group consensus, 116 criteria categorized by 13 groups were found to be applicable sustainable building planning and design criteria for Cambodia. Most of the criteria and their classifications are not only targeting to achieve sustainable buildings in the construction stage but also targeting to achieve sustainable buildings in the performance (operation and maintenance) and renovation stages. Moreover, there are four main categories and forty-two criteria concerning directly human-related dimensions, such as sustainable team formation and potential stakeholder involvement while other categories concerning about technical dimensions, such as sustainable site selection and design, water-energy efficient design, and building cost reduction.

Construction criteria for sustainable buildings are very important in maintaining the construction of sustainable buildings progressing in a right, safe, and sustainable way. These criteria are also important to further specify, reflect, and check again even if the constructors have followed the sustainable plan-design criteria for sustainable buildings. This is because the plan and design assignments are not really hundred percent the same with the construction assignments during the actual construction process. Thus, sustainable construction criteria are specifically essential to guide, monitor, and assess a sustainable building construction project and its progress to meet the sustainable building requirement during the construction stage. Based on the validated output data (validated criteria) demonstrated in Table A2, the construction criteria for sustainable buildings, including their classifications and descriptive importance, are variously covered on the multifunctional aspects of sustainability, and based on the group consensus, there are 112 criteria categorized by 13 groups found to be applicable sustainable building construction criteria for Cambodia. Principally, these construction criteria are not only targeting to achieve sustainable buildings in the construction stage but also targeting to achieving sustainable buildings in performance (operation and maintenance) and renovation stages. Moreover, as the construction stage is very technical and costly, and if we already constructed an unsustainable building, at the end we could not help or re-construct it. Therefore, assessment criteria will be beneficial in guiding the building construction in a right way.

In order to effectively and sustainably perform the function of constructed buildings, sustainable building performance (operation and maintenance) criteria are needed to guide the building owners and managers, as well as the building operators. They can follow the guiding criteria and/or sub-criteria and use them as a tool to monitor and assess their building performances in a sustainable way. Based on the validated output data (validated criteria) demonstrated in Table A3, the performance criteria for sustainable buildings, including their classifications and descriptive importance, are variously covered on many aspects of sustainability, and based on the group consensus, there are 67 criteria categorized by 12 groups found to be applicable sustainable building performance criteria for Cambodia. Within the performance (operation and maintenance) stage, most of the criteria are targeting to improve energy efficiency and reduce environmental impacts. As listed in the table, most of the criteria are related to managing the systems effectively, using the appliances efficiently, and maintaining the equipment and facilities properly.

The renovation criteria for sustainable buildings are also very important and needed to monitor and assess the building renovation towards achieving sustainable and highperformance buildings. Sustainable building renovation criteria are also important to use as a tool to monitor and assess a sustainable building renovation project and maintain its sustainability progress. Based on the validated output data (validated criteria) demonstrated in Table A4, renovation criteria for sustainable buildings, including their classifications and descriptive importance, are variously covered on many aspects of sustainability, 
and based on the group consensus, there are 56 criteria categorized by 12 groups found to be applicable sustainable building renovation criteria for Cambodia. Most of the criteria and/or sub-criteria are not only targeting to achieve sustainable building renovation in the renovation planning and design but also aiming to achieve sustainable buildings in all stages after renovation, especially in the performance (operation and maintenance) stage. As it is also related to re-designing, the plan-design criteria for sustainable buildings can also be partially applied to guiding a sustainable building renovation project.

\section{User Notes}

This paper revealed that sustainable building criteria for the planning and design stage quite a lot compared to construction, performance, and renovation stages. These criteria are almost twice compared to the performance and renovation criteria whereas comparable to the construction criteria. This shows that the planning and design stage is not only the earlier stage for a sustainable building project to take consideration but also it is the stage that we have to have well-planned and put more efforts on. This confirms that we need a comprehensive planning and inclusive design in order to achieve a sustainable building project. By having a proper planning and design in the beginning, it is a good and smart start towards achieving building sustainability in all stages.

In general, most of the buildings have been successfully registered and certified as sustainable buildings by their construction. In this case, we see that if the constructed building was not qualified as a sustainable building, we could not help because it was already built. Therefore, putting many efforts and getting qualified since the beginning would be the best choice. With this regard, sustainable building planning and design criteria are very important to monitor and assess the sustainable building project to getting qualified since the beginning. Establishing a sustainable building certification system for the planning and design stage can also provide benefits to both building owners and authorized evaluators (the government or independent institution). The government or independent evaluators can enhance their works leading to having more buildings qualified as sustainable buildings whereas the owners can promote their buildings and sells after successfully obtaining the sustainable building planning and design certificate.

This paper reviewed the data by collecting, combining, and validating sustainable building planning and design, construction, performance (operation and maintenance), and renovation criteria based on a general group consensus. However, in order to verify the levels of importance of these criteria is normally required a decision support tool. Systematizing these criteria by using a decision support tool with experts or relevant stakeholders in Cambodia is also important; for example, participatory system dynamics modelling is quite significant [19]. The technique to verify their priority weights in Cambodia is also significant, especially the technique using a pairwise comparison method to analyze the importance of criteria (priority weights). For example, AHP (analytic hierarchy process) and ANP (analytic network process) are the techniques using pairwise comparison. Especially, the AHP technique was found to be significant to verify the relative importance (priority weight) [20]. Therefore, future research applying AHP to verify the relative weights of these criteria in Cambodia would be a significant contribution.

Author Contributions: Conceptualization, P.C.; Methodologies, P.C.; Plan-Design Criteria Review, P.C., K.K., H.K.U., T.T., K.E., S.U., L.S., S.E. and H.T.; Construction Criteria Review, P.C., S.M., O.P., R.S., M.L., P.A. and M.R.P.; Performance Criteria Review, P.C., R.L., C.V., C.V.C., M.S., and S.V.; Renovation Criteria Review, P.C., L.M., O.H., S.P., S.S. and Y.C.; Validation, All Authors; WritingOriginal Draft, P.C.; Writing-Review and Editing, All Authors.

Funding: This research received no external funding.

Institutional Review Board Statement: Not applicable.

Informed Consent Statement: Not applicable.

Conflicts of Interest: The authors declare no conflict of interest. 


\section{Appendix A. Sustainable Building Plan-Design, Construction, Performance and Renovation Criteria}

Table A1. Sustainable building plan-design criteria.

\begin{tabular}{|c|c|c|c|}
\hline Category & Criteria & Description & Ref. \\
\hline \multirow{11}{*}{$\begin{array}{l}\text { Sustainable Project } \\
\text { Orientation }\end{array}$} & Sustainability brainstorming & $\begin{array}{l}\text { Introducing sustainability principles to the team members can provide a better work outcome by improving the cooperative work } \\
\text { in all the building systems to achieve a sustainable mission. }\end{array}$ & {$[21,22]$} \\
\hline & Sustainability goal setting & $\begin{array}{l}\text { Early setting sustainability goals is quite important, and a proper set of these goals and project priorities can make the framework } \\
\text { clear that will help in the later decision makings in the project. }\end{array}$ & {$[18,21]$} \\
\hline & Sustainable project briefing & $\begin{array}{l}\text { Pre-introduction, before the project starts, will sup-port the effort and effectiveness of the design towards achieving green building } \\
\text { and sustainability goals, as well as cost-effectiveness. }\end{array}$ & {$[22,23]$} \\
\hline & Sustainable project baseline & $\begin{array}{l}\text { During defining project scope and charter, design drawing, management plan, and contract, it is crucial to include the sustainability } \\
\text { re-quirement in order to select the best option to achieve the target of sustainability. }\end{array}$ & {$[21,24]$} \\
\hline & Code of behaviors & $\begin{array}{l}\text { A set of conventional principles and expectations for a particu-lar group can be a useful regulatory tool and setting the early criteria } \\
\text { can help achieve the goals of sustainability for the associated stakeholders. }\end{array}$ & [21] \\
\hline & Governing rule orientation & $\begin{array}{l}\text { Stakeholders with appropriate skills and competencies are driven or get approved by the strong governing rules or the effective } \\
\text { monitoring principles in terms of using sustainable technology for environmental advantages. }\end{array}$ & [24] \\
\hline & Integrated key dimensions & $\begin{array}{l}\text { Environmental, socio-cultural, and economic dimen-sions have to be integrated in sustainable building planning and design, and } \\
\text { achieving these dimensions together will lead to achieving the sustainability of buildings. }\end{array}$ & [22] \\
\hline & Stakeholder orientation & $\begin{array}{l}\text { The orientation of stakeholders is very important to a sus-tainable building project, especially during the planning and design stage. } \\
\text { Involving them in the sector is encouraged to experience the sustainable benefits. }\end{array}$ & [24] \\
\hline & Project cost intimation & $\begin{array}{l}\text { The building project director needs to prepare an actualized expense to the clients corresponding to the efforts of stakeholders in } \\
\text { terms of sustaina-ble design and construction intention. }\end{array}$ & [24] \\
\hline & Incentive support provision & $\begin{array}{l}\text { Incentives play an important role in sustainability promotion. Incentives can be provided in terms of money or others to the } \\
\text { stakeholders to improve the working performance, including the sustainability perception. }\end{array}$ & [21] \\
\hline & Available material briefing & $\begin{array}{l}\text { The comprehension of material sources, characteris-tics, and certification is encouraged essentially to stakeholders to understand } \\
\text { the availability of sustainable materials in the construction industry. }\end{array}$ & [24] \\
\hline \multirow{2}{*}{$\begin{array}{l}\text { Sustainable Project } \\
\text { Planning }\end{array}$} & Early engagement & $\begin{array}{l}\text { By bringing all stakeholders to collaborate and share ideas as early as possible in plan-ning stage, the project can be achieved at a } \\
\text { lower cost. Well-functioned team in the early stage tends to show better quality in the following preparation. }\end{array}$ & [24] \\
\hline & Design charrette & $\begin{array}{l}\text { A design charrette, an intense period of design or planning activ-ities, to the regular progress meeting since the beginning in the } \\
\text { planning stage can im-prove the effectiveness in communication and the exchanges of ideas. }\end{array}$ & [24] \\
\hline
\end{tabular}




\begin{tabular}{|c|c|c|c|}
\hline & Working together & $\begin{array}{l}\text { When various groups of stakeholders work together in the early process using effective communication, which includes engineering, } \\
\text { operation and maintenance, and outsider, a sustainable building project can provide a better result. }\end{array}$ & [21] \\
\hline & Inclusive documenting & $\begin{array}{l}\text { The incorporation of sustainability and integrated sustainable design requirements into the comprehensive project documentation } \\
\text { and project plans are crucial for delivering a successful project. }\end{array}$ & {$[21,24]$} \\
\hline & Commissioning process & $\begin{array}{l}\text { Adding the commissioning process in the planning stage can ensure that the system performs as designed, and the issue in the } \\
\text { system can be solved in the pre-design stage which can reduce the cost spent. }\end{array}$ & [24] \\
\hline & Whole-building design & $\begin{array}{l}\text { A cost-effective building can be achieved through the use of the whole-building design approach (corporates the knowledge from } \\
\text { all relevant stakeholders) to maximize multiple benefits resulting from independencies in the systems. }\end{array}$ & {$[21,25]$} \\
\hline & Perspective reflection & $\begin{array}{l}\text { Sustainable development considers all the relevant stakeholders' perspectives in decision making as the planning and design process } \\
\text { can determine the future performance of the building. }\end{array}$ & [24] \\
\hline & End-user reflection & $\begin{array}{l}\text { The design fulfilling the community's needs and performing its purposes well tends to be given more care and sustainable; thus, the } \\
\text { reflection from the users or representatives of end-users is important in the planning and design stage. }\end{array}$ & [24] \\
\hline \multirow{9}{*}{$\begin{array}{l}\text { Sustainable Team } \\
\text { Formation }\end{array}$} & Sustainability qualification & $\begin{array}{l}\text { Selecting participants should consider the quality and capacity in the focus of sustainability, as well as the familiarity of product } \\
\text { type, market, and experiences with the project, which can contribute to the success of the project. }\end{array}$ & {$[21,24]$} \\
\hline & Competence qualification & $\begin{array}{l}\text { Professionals of the team who will work throughout the whole process are required to be certified in terms of engineering ethics and } \\
\text { sustainability concept awareness since the concept has recently popped up and is being developed. }\end{array}$ & {$[21,22]$} \\
\hline & Individual qualification & $\begin{array}{l}\text { Towards forming a qualified sustainability team, the comprehensive knowledge and understanding of sustainability concepts of } \\
\text { each member are important that can make the project achieved the desired future results. }\end{array}$ & {$[22,24]$} \\
\hline & Integrated project team & $\begin{array}{l}\text { The core integrated project team with a cross-functional system allows different parties to work closely and understand each other's } \\
\text { concerns and problems, which can allow all the stakeholders to be actively engaged in the planning process to achieve a sustainable } \\
\text { building planning and design project. }\end{array}$ & {$[21,24]$} \\
\hline & Sustainability missions & $\begin{array}{l}\text { The formed sustainability team, selected sustainability partners, and all relevant stakeholders are well informed of the sustainability } \\
\text { missions that need to be achieved at the end of the project's completion. }\end{array}$ & {$[21,22]$} \\
\hline & Sustainability bureau & $\begin{array}{l}\text { The sustainability-operational bureau should be established with a group of sustainability specialists in order to maintain and } \\
\text { coordinate the sustainability goals and missions of the project with the design team. }\end{array}$ & {$[24,26]$} \\
\hline & Collaborative session & $\begin{array}{l}\text { Similar to a design charrette, an intense period of design or planning activities, the collaborative session should be a multi-day } \\
\text { design/planning activities that produces consensus among stakeholders through the design phase. }\end{array}$ & [27] \\
\hline & Progress meetings & $\begin{array}{l}\text { Progress meetings are also important. They are significant occurrences of concluding the involving candidates' ideas and availability } \\
\text { to meet the possible peak of the project goals and missions before the construction starts. }\end{array}$ & [17] \\
\hline & Lenders and investors & $\begin{array}{l}\text { Lenders can be introduced in sustainable project knowledge; therefore, they can take the chance to spread green and sustainable } \\
\text { concepts and understand the investors to feel the encouragement and advantages from the concepts. }\end{array}$ & [17] \\
\hline
\end{tabular}


Construction managers

Sustainability coordinators

Facility managers
The knowledge of selecting structural materials and construction strategies is another important factor to achieve sustainable building design, and construction managers have a good understanding and knowledge on this matter.

Sustainability coordinators provide advice or solutions to project stakeholders in the company to obtain sustainability goals and provide recommendations on reducing environmental impacts and carbon footprint.

Facility managers (who may or may not be the owners) have an important role in the performance stage of the building as they monitor, take care of, and maintain the whole operation after the building is completed.

\begin{tabular}{|c|c|c|}
\hline Local stakeholders & $\begin{array}{l}\text { The involvement from local communities or local administration can ensure that the building planning follows and satisfies the } \\
\text { municipality's regulations and needs, as well as the achievement of sustainability goals. }\end{array}$ & {$[17,24]$} \\
\hline After-design stakeholders & $\begin{array}{l}\text { The stakeholders who are always along after architects and engineers finish the drawing and planning. A good communication with } \\
\text { them will avoid the extra cost and ensure the process of green materials supply, confidentially. }\end{array}$ & [17] \\
\hline Civil engineers & $\begin{array}{l}\text { The roles of civil engineers in the sustainable building planning and design stage can help to address the site problems, especially } \\
\text { for potential hazard issues, such as environmentally polluted sites, and for the water-related issues, such as water resource } \\
\text { management and stormwater management. }\end{array}$ & {$[17,30]$} \\
\hline Mechanical engineers & $\begin{array}{l}\text { Mechanical engineers have important roles in distributing and supplying energy, such as in heating and cooling systems. Having } \\
\text { them involved in sustainable building project planning can lead to having a good plan for reducing energy consumption and } \\
\text { environmental impacts of buildings. }\end{array}$ & [30] \\
\hline Electrical engineers & $\begin{array}{l}\text { Electrical engineers are responsible for circuit, wiring, and telecommunication design, as well as electrical lighting in some cases. } \\
\text { Having them involved in sustainable building planning can lead to reducing a large amount of energy consumption, especially in } \\
\text { commercial buildings. }\end{array}$ & [30] \\
\hline Plumbing engineers & $\begin{array}{l}\text { Plumbing engineers have important roles in the use of water fixtures and the connection of water systems. As the water becomes } \\
\text { scarcer, having them involved in sustainable building planning is very important and can lead to improving the use of water and } \\
\text { sustainability. }\end{array}$ & [30] \\
\hline Design professionals & $\begin{array}{l}\text { Sustainability design professionals are very important and their competence must be certified or qualified in terms of architectural } \\
\text { planning and drawing with the understanding of sustainability concepts and principles. }\end{array}$ & {$[17,30]$} \\
\hline Interior designers & $\begin{array}{l}\text { Interior designers play an important role in providing good indoor air quality and the sustainability of materials and furniture, such } \\
\text { as the resources used for manufacturing, and life duration, as well as the potentials for recycling because interior designers are the } \\
\text { ones who plan and design the whole space. }\end{array}$ & {$[30]$} \\
\hline Landscape architects & $\begin{array}{l}\text { Landscape architects normally cover sustainable landscape design. Their roles are to maintain the sustainable plan and design in } \\
\text { terms of greenery and sustainable landscape in order to make the construction more alive. }\end{array}$ & {$[17,30]$} \\
\hline In-house employees & $\begin{array}{l}\text { The project personnel and vendors have important roles in making sure that sustainability concepts are included in their works, and } \\
\text { adherence to the company's sustainable development methodology is realized. }\end{array}$ & {$[17,24]$} \\
\hline Market representatives & $\begin{array}{l}\text { Market representatives such as brokers, lenders, and appraisers play an important role in the determination of the asset's value and } \\
\text { viability, which is crucial to be introduced in the sustainability and project delivery process. }\end{array}$ & [24] \\
\hline
\end{tabular}

Potential 


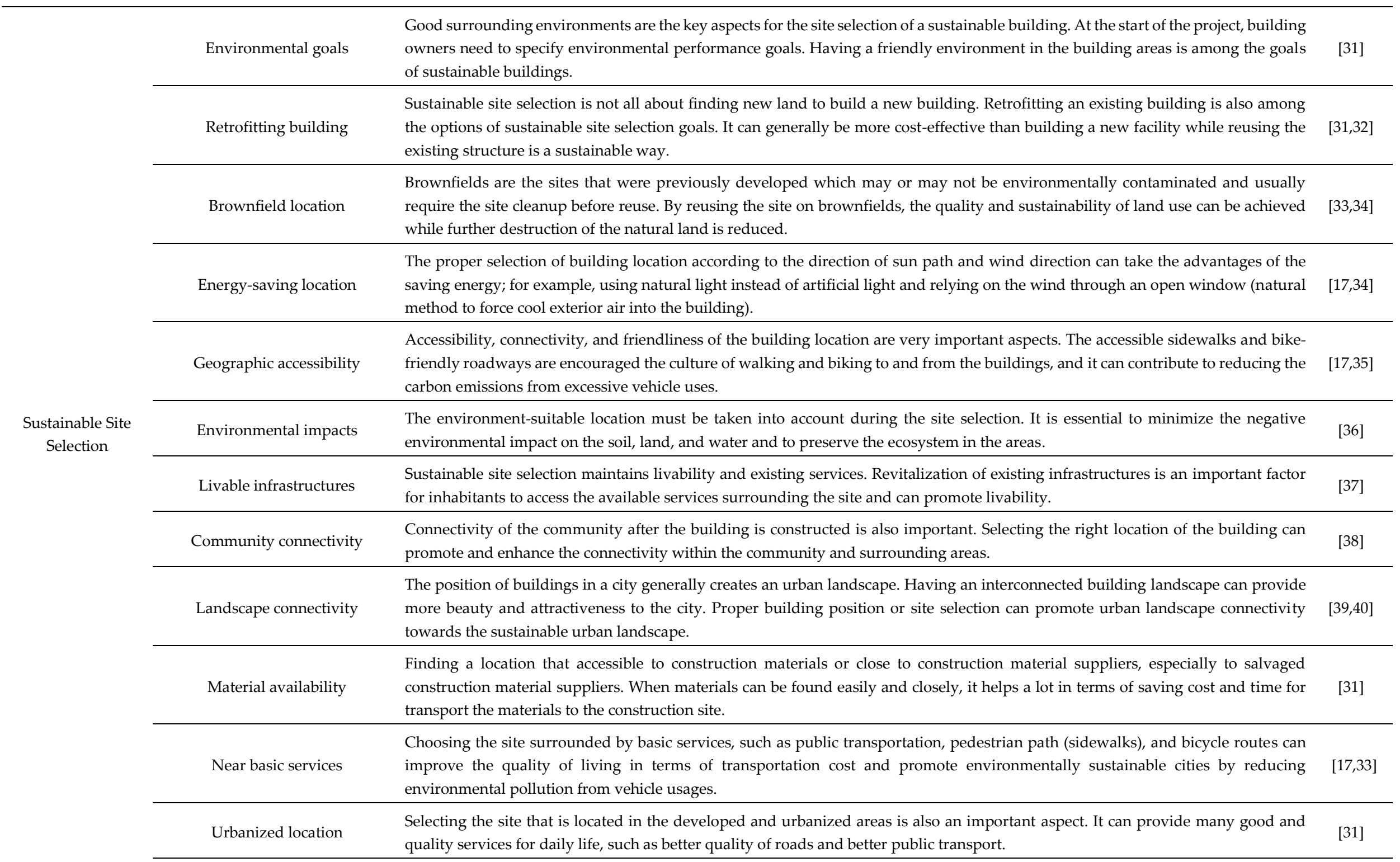


Mixed-use location

Desirable location

Ecological preservation

Smart outdoor lighting

Passive solar design

Surface water design

Sustainable Site Design

Irrigation system design

Mixed-use development is a form of urban development or zoning that combines residential, commercial, cultural, institutional and/or entertainment uses into a single space. If the building is constructed in this area, it will become a building used for many purposes and to promote social inclusion.

Convenience is a welcome part of daily life. A convenient location for building construction is a very important aspect and is a desirable location. It can make life more pleasant, easier, and safer. It is a good decision to choose a place that has a desirable amenity for sustainable development.

Sustainable site design aims to maintain ecosystems in the area. It is a strategy to preserve and improve the site's ecological integrity and biodiversity by providing shelter to wildlife and planting native or local species.

Artificial outdoor light can have many impacts on the environment, such as disrupting the natural pattern of light and dark that can affect the animal's sleep cycle, plant growth, and glare and temporary blindness, as well as waste energy. Therefore, smart outdoor lighting design can reduce the above problems.

The design of clustering homes, dense communities with open spaces that can be used as a recreational or environmental park (similar to the Borey development situation), can increase the site value and promote the sense of community while preserving open spaces and landscapes.

Passive solar design is the design using the natural energy of the building's site as resources, such as wind and sunlight, as well as green vegetation that provides good conditions for ventilation, heating, and cooling purposes.

Surface water design is the design of the site features to minimize the erosion and rainwater runoff, as well as water installation separators, while harvesting, storing, and treating rainwater for internal use.

The irrigation system design must be a smart and strategic design. Few strategies should be conducted such as harvesting rainwater or wastewater for irrigation systems and using water-efficient plants and irrigation.

Lower UHI effect design In most cities, the design that can minimize the urban heat island effect is very important. It can be achieved by maximizing green spaces and pervious surfaces and providing shading and more effective strategies to practice.

The design that can minimize the site disturbance usually decreases the impact of new building construction on the site and the local

Site protection design ecosystem. This can be made by minimizing the part of the site impacted by development, limiting grading and soil erosion, and safeguarding existing plants and other natural resources.

Introducing low emission design can promote building sustainability by producing clean and renewable sources of energy in the area and collecting the stored gases to prevent it from affecting the atmosphere.

Compact building design uses the least amount of land for development and supporting infrastructure that is reasonable under the circumstances. It leads to reduce pollution and cost of vehicle usage and improve social interaction.

Compact building design Sustainable landscape design can provide an effective irrigation system to reduce the amount of water usage in irrigation. Sustainable landscape design can also help reduce the urban heat island effect in the city. 


\begin{tabular}{|c|c|c|c|}
\hline \multirow{4}{*}{$\begin{array}{l}\text { Resource } \\
\text { Conservation Plan }\end{array}$} & Land use conservation & $\begin{array}{l}\text { Urban expansion is one of the concerns in both developed and developing countries. Therefore, the use of land should be optimized } \\
\text { by effective planning. Preserving undeveloped land and open space is also important to reduce urban sprawl towards reducing car } \\
\text { usage and transportation needs. }\end{array}$ & [32] \\
\hline & Material conservation & $\begin{array}{l}\text { Most raw materials are extracted from natural resources. Therefore, the selection of materials and waste management should be } \\
\text { taken into consideration at the planning and design phases. Using materials efficiently can also save cost, reduce waste, and preserve } \\
\text { the environment and natural resources. }\end{array}$ & {$[32,46]$} \\
\hline & Water conservation & $\begin{array}{l}\text { A huge amount of water has been consumed to operate throughout the life cycle of the building which can lead to a water crisis. } \\
\text { Hence, water conservation planning should be developed during the planning and design phase in order to mitigate the utmost } \\
\text { concern for environmental issues. }\end{array}$ & {$[47,48]$} \\
\hline & Energy conservation & $\begin{array}{l}\text { The large amounts of energy and resources are consumed throughout the entire process of construction. It is related to all } \\
\text { construction- and operation-energizing costs, increasing energy supply, and producing air pollution (CO2 emissions). Thus, strategic } \\
\text { planning should be considered beforehand. }\end{array}$ & {$[32,34]$} \\
\hline \multirow{8}{*}{$\begin{array}{c}\text { Buiding Cost } \\
\text { Reduction Plan }\end{array}$} & Material cost saving & $\begin{array}{l}\text { Local manufacture products are cheaper and more convenient than the imported materials. A case in China shows that it saves } 10.9 \% \\
\text { compared to the average cost of a normal building whereas the LEED rating standard estimates the cost on the local material usage } \\
\text { or eliminates some features to save overall costs. }\end{array}$ & [49] \\
\hline & Energy cost saving & $\begin{array}{l}\text { The energy consumption cost has been discovered to be higher than normal equipment. A study shows that the total energy cost has } \\
\text { covered more than the excessive cost of constructing the building. By having energy cost saving plan and design, the building, in } \\
\text { the long run, is able to generate its useful features for power consumption and save the electricity cost by a great amount. }\end{array}$ & {$[50]$} \\
\hline & Productive worth & $\begin{array}{l}\text { It is able to reach worthiness through green building design towards sustainable productivity of users. All the features such as } \\
\text { heating, lighting, and energy-efficient equipment are very costly, but at the same time, a sustainable energy consumption planning } \\
\text { can lead to anticipate productive gain of the building. }\end{array}$ & [51] \\
\hline & Design cost saving & $\begin{array}{l}\text { Design cost saving is also an important aspect to achieve sustainable cost management of the building. The varieties of value and } \\
\text { cost-saving encountered run parallel with making plans and design of the building. }\end{array}$ & [49] \\
\hline & Initial cost reduction & $\begin{array}{l}\text { The initial (entire) cost, such as the cost of land, materials, and construction, is a large amount. We should consider some reduction } \\
\text { because the economic evaluation of the initial cost is the primary concern for the client. A reduction plan should be taken into } \\
\text { consideration at the design phase to make the project feasible. }\end{array}$ & {$[32,52]$} \\
\hline & Operation cost reduction & $\begin{array}{l}\text { The operation cost will exist during the building getting ready to serve or after the building construction is finished. Thus, it should } \\
\text { be estimated in the design phase in order to develop the strategic method to minimize the operation costs which can reduce the total } \\
\text { cost over a long-term period. }\end{array}$ & {$[32,52]$} \\
\hline & Maintenance cost reduction & $\begin{array}{l}\text { The maintenance cost happens during the performance stage. Having a well-planned maintenance cost reduction in advance during } \\
\text { the planning and design stage of the buildings can help reduce the maintenance cost of the constructed buildings during the } \\
\text { performance stage. }\end{array}$ & {$[52,53]$} \\
\hline & Retrofitting cost planning & $\begin{array}{l}\text { Building cost reduction plan is not only in new building construction. Retrofitting an existing building is also required a cost } \\
\text { reduction plan. It can provide the project owner more cost-effectively while reusing existing facilities. }\end{array}$ & [32] \\
\hline
\end{tabular}




\begin{tabular}{|c|c|c|c|}
\hline \multirow{7}{*}{$\begin{array}{l}\text { Sustainable Building } \\
\text { Space Design }\end{array}$} & Efficient building shape & $\begin{array}{l}\text { Some building shapes use resources more efficiently than others; so, efficient building shapes should be considered in the plan. Ex. } \\
\text { a square-shaped building uses lesser resources than the rectangular one for the same floor area. }\end{array}$ & {$[54,55]$} \\
\hline & Lower building footprint & $\begin{array}{l}\text { As the size of the household decreases and the cost of building increases, smaller units of apartments or homes become more } \\
\text { demanded. Smaller buildings use lesser resources to construct as well as require less operating energy. }\end{array}$ & {$[17,56]$} \\
\hline & Space utilization strategy & $\begin{array}{l}\text { The effective design with the full use of spaces for small and compact units can provide a fully functional apartment or home that } \\
\text { uses lesser resources and energy. Therefore, space utilization strategies are also important. }\end{array}$ & {$[17,57]$} \\
\hline & Elimination of corridors & $\begin{array}{l}\text { The elimination of the corridors or hallways through organizing the floor plan around the living room can efficiently transform the } \\
\text { free spaces into the living spaces; in particular, it can save some spaces. }\end{array}$ & [17] \\
\hline & Creating common spaces & $\begin{array}{l}\text { By providing common spaces, it can create efficient use of the spaces. For example, the spaces with the shared facilities for having } \\
\text { meals and meetings can improve the use of spaces and create more sense of community. }\end{array}$ & {$[25,43]$} \\
\hline & Multifunctional spaces & $\begin{array}{l}\text { Some spaces can serve multiple functions. Furthermore, some spaces can have a future change in use. Therefore, the plan for open } \\
\text { layout and the reduction in the interior wall can create more flexibility in space used. }\end{array}$ & {$[17,52]$} \\
\hline & Unnecessary item removal & $\begin{array}{l}\text { By eliminating finishes or unnecessary items, such as drop panel ceiling and building storages that are recessed to the floor, can } \\
\text { provide an opportunity for designers to create a more functional space or reduce the building size. }\end{array}$ & {$[17,25]$} \\
\hline \multirow{7}{*}{$\begin{array}{l}\text { Indoor } \\
\text { Environmental } \\
\text { Management }\end{array}$} & Indoor light control & $\begin{array}{l}\text { A building with good quality of light allows the natural sunlight or uses the lighting system to work as similar to the natural light } \\
\text { as possible. With the right amount of light, it helps users to concentrate more and be productive. }\end{array}$ & {$[34,51]$} \\
\hline & Thermal management & $\begin{array}{l}\text { With good control, we can benefit from the energy consumption that is supposed to be used by the heater or air conditioner to } \\
\text { moderate the comfort level of temperature which boosts productivity and concentration. }\end{array}$ & {$[29,51]$} \\
\hline & Ventilation management & $\begin{array}{l}\text { With suitable natural ventilation, the process can help promote users' well-being and productivity and save electricity bills. It begins } \\
\text { with the site selection where there is an adequate amount of free space of the air flow. }\end{array}$ & {$[58]$} \\
\hline & Humidity control planning & $\begin{array}{l}\text { With the right amount of moisture content of the air, people can avoid dehydration due to dryness of the air that can pose many } \\
\text { problems to our skin and respiratory system. Furthermore, when excessing humidity up to } 16 \% \text { can lead to molding in wood which } \\
\text { causes unhealthy air quality as well. }\end{array}$ & [50] \\
\hline & Indoor carbon reduction & $\begin{array}{l}\text { Carbon can be produced as a form of carbon dioxide (CO2) from any combustion machine and metabolism of the organism's body. } \\
\text { High amounts of the } \mathrm{CO} 2 \text { level in the building commonly occur in grounded areas, such as office spaces and conference halls, and } \\
\text { also in tidy spaces, lack of ventilation. Hence, the design for indoor carbon control is important to reduce } \mathrm{CO} 2 \text { emissions. }\end{array}$ & [59] \\
\hline & Noise pollution control & $\begin{array}{l}\text { Noise from appliances, such as lighting, ventilation systems, and motor, and from other sources can bring some discomfort and } \\
\text { sometimes affect the health. Some subtle background noise can also cause irritation and loss of productivity. Therefore, the design } \\
\text { for noise pollution control is important. }\end{array}$ & [34] \\
\hline & Odor pollution control & $\begin{array}{l}\text { The disturbing smell or odor pollution can be controlled by removing and isolating the contaminants that cause odor. Also, odor } \\
\text { pollution can be controlled by choosing and purchasing lesser odorous products. }\end{array}$ & [34] \\
\hline
\end{tabular}


Value aesthetic decisions

The provision of good views and connections between people and nature can contribute to improving the indoor environmental quality, including the color and shape of the building, the arrangement of the plants, the view on the walking path, and the design of the fountain or aquarium.

Hazardous risk mitigation

The risk mitigation plan to prevent any hazardous event like an earthquake, fire incident, flooding, and terrorism should be implemented to eliminate the loss of human life and physical resources and properties.

Some materials emit pollutants, such as volatile organic compounds, which can affect the health of the occupants and the environment; thus, those pollutant materials should not be accepted to use in a sustainable building.

Water use management in a building can be improved by utilizing an efficient system in the flow of handheld or sensor equipment,

Plumbing system management such as sensor toilets, urinals, showerheads, washing machines, and sinks. Thus, the design aiming to use this efficient system can save a lot of water and energy.

Dual plumbing installation plambing installation is also important for a sustainable building. It is useful in recycling water for toilet flushing or to have a greywater system recovering rainwater or not-potable water for site irrigation.

Sustainable Wate Management

A building usually requires storage to contain rainwater. Sustainable water storage is used to reduce water consumption supplied

Rainwater storage management by the authority by using rainwater as drinking water instead of in the rainy season. It is also used for reducing treated water consumption by using greywater for irrigation.

Proper pressure reduction plan A proper design can lower the pressure of the water that can correspond to the related parameter hydraulically, such as the water flow rate. This is also an effective way to control the water-saving system.

Hot water recirculating system is also important. A proper design can enhance the distribution to conserve water which can lead to reducing the wastewater from the warming duration that the users are waiting for.

Water recirculation management

Renewable energy plan

The design planning for promoting renewable energies can reduce the environmental impacts of the building. Renewable energies, such as solar and wind energies, are perceived to be a clean source of energies and contributes to reducing air pollution and carbon footprint, especially in urban areas.

The effective use of daylighting while preventing heat gain can reduce building energy consumption. The daylighting design

Effective daylighting design strategies for providing daylighting include placing the windows according to the orientation of the building as well as equipping automatic lighting controls. Sustainable Energy The design to maximize the use of natural ventilation provides fresh air for occupants and can improve working productivity.

Natural ventilation design Moreover, the use of natural ventilation through an operable window can reduce the need for the cooling system; consequently, it saves cost and energy.

Energy optimization plan The use of building information modeling (BIM) can optimize the design of mechanical systems and the building shell in the design stage. Therefore, it can optimize energy consumption in the building.

Building insulation is very significant for thermal purposes. It is necessary to design a proper energy conservation system to reduce the heat surplus in warmer weather to conserve the energy in the building. 


\begin{tabular}{|c|c|c|c|}
\hline & Material choice-based design & $\begin{array}{l}\text { The design based on a wise choice of material selection can significantly reduce energy consumption in the building. Thus, the design } \\
\text { targeted to use sustainable materials will be leading in environment and cost-saving. }\end{array}$ & {$[23,32]$} \\
\hline \multirow{9}{*}{$\begin{array}{l}\text { Material Use } \\
\text { Planning and } \\
\text { Condition }\end{array}$} & No material pollution & $\begin{array}{l}\text { Pollution prevention by material selection must be included in the building plan. Low environmental pollution is caused by the } \\
\text { effort of the design during manufacturing and transportation. }\end{array}$ & {$[32,63]$} \\
\hline & No chemical pollution & $\begin{array}{l}\text { Hazardous chemicals can be natural chemicals (such as lead) or synthetic (such as dioxin) which can affect health. Thus, hazardous } \\
\text { chemical reduction is necessary and must be included in the material selection plan. }\end{array}$ & {$[34,61]$} \\
\hline & Local material promotion & $\begin{array}{l}\text { Promoting local materials by using locally manufactured products can minimize the environmental impacts through less distance } \\
\text { transportation. Those products or materials can also be found at a low cost. }\end{array}$ & {$[32,61]$} \\
\hline & Energy-efficient materials & $\begin{array}{l}\text { Using energy-efficient materials is also a sustainable building goal. Materials that improve energy efficiency use less energy. } \\
\text { Therefore, those materials produce less environmental impacts and air pollution. An example can be the materials of the building } \\
\text { envelope that control the solar heat gain. }\end{array}$ & [61] \\
\hline & Efficient embodied energy & $\begin{array}{l}\text { The total invested energy, known as embodied energy, is required to produce the materials or products. Hence, the best use of } \\
\text { materials has to be promoted to avoid the embodied energy being wasted. For example, the use of 500-year-old trees to make papers } \\
\text { is not an efficient use of embodied energy. }\end{array}$ & {$[34,61]$} \\
\hline & Material durability & $\begin{array}{l}\text { Material durability is also an important aspect that should be included in the building plan. The material with great durability can } \\
\text { delay the frequency of material replacement, which can save resources and energy. }\end{array}$ & {$[35,64]$} \\
\hline & Integrated maintainability & $\begin{array}{l}\text { Maintainability refers to the ability of a facility that after the maintenance, the specific condition can be retained or restored. The } \\
\text { integration of maintainability usually starts right from the design stage. }\end{array}$ & {$[61,65]$} \\
\hline & Material waste control & $\begin{array}{l}\text { A proper waste control plan and management can minimize the use of natural resources by reusing construction wastes and } \\
\text { materials to the utmost possibility and managing the waste storage appropriately, especially for checking and controlling non- } \\
\text { preventable wastes and toxic materials. }\end{array}$ & {$[66,67]$} \\
\hline & Recycled material use & $\begin{array}{l}\text { Recycled content has been made from pre-and post-consumer materials. The use of recyclable materials can contribute to minimizing } \\
\text { waste generation and reducing environmental impacts. }\end{array}$ & {$[34,68]$} \\
\hline Category & Criteria & Description & Ref. \\
\hline \multirow{3}{*}{$\begin{array}{c}\text { Efficient Use of } \\
\text { Material Resources }\end{array}$} & Life cycle assessment & $\begin{array}{l}\text { In the early construction stage, it is an optimization assessment on environmental impacts and life cycle cost building which includes } \\
\text { energy consumption, resources used, and greenhouse gas and pollution production. }\end{array}$ & {$[69,70]$} \\
\hline & Certain material costs & $\begin{array}{l}\text { It measures the real financial benefits of a certain material. It takes into account the cost of purchasing, installing, expected life span, } \\
\text { replacement, and maintenance compared to the material being replaced. }\end{array}$ & {$[18,71]$} \\
\hline & Total energy analysis & $\begin{array}{l}\text { Analysis of the total energy being used for the production and transportation of materials is an embodied energy analysis. It can be } \\
\text { used to access the right materials that decrease sufficient amounts of energy consumption. }\end{array}$ & {$[72,73]$} \\
\hline
\end{tabular}

doi:

更

更

更

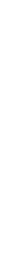

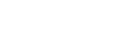




\begin{tabular}{|c|c|c|c|}
\hline & Material sustainability & $\begin{array}{l}\text { The performance and sustainability of the construction materials need to be properly assessed and evaluated. When construction } \\
\text { material selection cannot be fully demonstrated by the embodied energy analysis, the green building rating system should be used } \\
\text { for this assessment and evaluation. }\end{array}$ & {$[74-76]$} \\
\hline & Using local materials & $\begin{array}{l}\text { Locally available materials are normally coming from a } 500 \text {-mile radius. Using the local materials can help reduce the embodied } \\
\text { energy of materials, transportation, fasten the construction time, and reduce the energy spent on the dwelling. }\end{array}$ & {$[77,78]$} \\
\hline & Material resilience & $\begin{array}{l}\text { The resilience of materials is very important. This aspect involves selecting materials that account for cost, maintenance (cost and } \\
\text { period), recyclability, low-environmental impact, durability, and long-lasting. }\end{array}$ & {$[17,79]$} \\
\hline & Recycled materials & $\begin{array}{l}\text { Using recycled materials is an efficient way of using materials and helps reduce the waste amount and save the environment. It is } \\
\text { very significant due to the limitation of raw materials in construction. Recycled materials may come from construction wastes, } \\
\text { industries, residents, and businesses. }\end{array}$ & {$[80,81]$} \\
\hline & Salvaged materials & $\begin{array}{l}\text { Salvaged and reused materials are materials suitable to reuse for building construction and should not contain any hazardous } \\
\text { substances. They can be from on-side, in case of renovation, and off-site locations. }\end{array}$ & {$[81,82]$} \\
\hline & Waste management & $\begin{array}{l}\text { In order to get qualified as a sustainable building, it is compulsory to manage waste and avoid pollution. Therefore, experts need to } \\
\text { assess the optimization of waste management for sustainable building. }\end{array}$ & {$[83,84]$} \\
\hline & Cost-benefit analysis & $\begin{array}{l}\text { Cost-benefit analysis is important to show that vertical greenery systems are economically sustainable. In addition to this, incentives, } \\
\text { like tax reduction, can lower the personal initial costs of the materials and promote green systems. }\end{array}$ & {$[85,86]$} \\
\hline \multirow{7}{*}{$\begin{array}{l}\text { Efficient Building } \\
\text { and Roofing } \\
\text { Systems }\end{array}$} & Fly ash concrete & $\begin{array}{l}\text { Fly ash can be used to replace the Portland cement from } 15 \text { to } 20 \% \text { of cementitious materials. It reduces the mixing water requirement, } \\
\text { heat from hydration in the curing process, the impact on the environment, energy, and } \mathrm{CO} 2 \text { emissions at the same time and gives a } \\
\text { better strength performance to the concrete. }\end{array}$ & {$[17,87]$} \\
\hline & Recycled aggregate & $\begin{array}{l}\text { Recycled aggregate concrete is considered one of the most recognized sustainable construction materials due to its reduction in raw } \\
\text { materials (natural aggregate) usage. It is composed of construction wastes that undergo certain procedures that will convert into } \\
\text { usable aggregates. }\end{array}$ & [88-90] \\
\hline & Insulating concrete forms & $\begin{array}{l}\text { Insulating concrete forms are the system foam insulating formwork for reinforced concrete walls that permanently stay in place. } \\
\text { They are used to maintain the temperature indoors, warm in winter, and cool in summer. Besides that, they also function as acoustic } \\
\text { foam for the building. }\end{array}$ & {$[79,91]$} \\
\hline & Engineered trusses & $\begin{array}{l}\text { Engineered trusses are truly a sustainable roofing system due to their low weight, which refers to the decrease of material usage and } \\
\text { high performance with the adequate design of the trusses. }\end{array}$ & {$[17,92]$} \\
\hline & Parallel chord trusses & $\begin{array}{l}\text { Parallel chord trusses maximize the interior spaces because the top and bottom chords are parallel to one another; the roof slope and } \\
\text { cathedral ceiling are both the same angle in these homes. }\end{array}$ & {$[17,93]$} \\
\hline & Scissor trusses & $\begin{array}{l}\text { Scissor trusses produce a finished cathedral ceiling which is half the pitch of the roof. The area can be utilized for attic or loft spaces } \\
\text { with a standard floor if the roof pitch is steep enough. }\end{array}$ & {$[17,93]$} \\
\hline & Organic shingles & $\begin{array}{l}\text { Recycled-content organic asphalt shingles work similarly to fiberglass asphalt shingles for the roof. It uses recycled materials, such } \\
\text { as waste paper and/or reclaimed mineral slag in their aggregate surface. }\end{array}$ & {$[79,94]$} \\
\hline
\end{tabular}




\begin{tabular}{|c|c|c|c|}
\hline & Cool roof system & $\begin{array}{l}\text { A cool roof system is popular in sustainable roofing for three main reasons: It reduces the energy use in the building with its reflective } \\
\text { coating, avoids the green office effect, and reduces urban heat effect since its surface is not dark. }\end{array}$ & {$[95,96]$} \\
\hline & Green roof system & $\begin{array}{l}\text { A green roof system is an extension of the existing roof which involves, at a minimum, high-quality waterproofing, root repellent } \\
\text { system, drainage system, filter cloth, a lightweight growing medium, and plants. It is a sustainable design concept aiming to reduce } \\
\text { heat and improve energy efficiency. }\end{array}$ & {$[97,98]$} \\
\hline \multirow{5}{*}{$\begin{array}{l}\text { Sustainable } \\
\text { Windows and Doors }\end{array}$} & Louvered windows & $\begin{array}{l}\text { A louvered window is a window composed of parallel glass, acrylic, or wooden louvers set in a frame. It is a type of window blind } \\
\text { or shutter that has horizontal slats that increase natural ventilation and cool temperature of the building. }\end{array}$ & {$[99,100]$} \\
\hline & Vinyl sash windows & $\begin{array}{l}\text { Vinyl sash windows are top-shelf windows that hold the glass and the framework around the glass to keep it in place. It contains } \\
\text { solar heat gain coefficient and visible transmittance. }\end{array}$ & {$[17,101]$} \\
\hline & Low emissivity glass & $\begin{array}{l}\text { Low emissivity glass is an essential part of most energy-efficient windows and doors. It has a surface coating that operates as follows: } \\
\text { It allows short wavelength heat from the sun to enter your home through the glazing. }\end{array}$ & {$[79,102]$} \\
\hline & Window sash kits & $\begin{array}{l}\text { Window sash kits are comprised of the sashes themselves, which come with insulated glass, new jamb liners, and hardware. They } \\
\text { are a simple and economical way to improve the thermal efficiency of the buildings. }\end{array}$ & {$[17,101]$} \\
\hline & Exterior doors & $\begin{array}{l}\text { The exterior doors or outside doors are also important aspects. They usually separate the interior of the home from the element. } \\
\text { They should be insulated units or wood units with composite cores. }\end{array}$ & [17] \\
\hline \multirow{7}{*}{$\begin{array}{l}\text { Air and Lighting } \\
\text { Quality } \\
\text { Management }\end{array}$} & Source pollution control & $\begin{array}{l}\text { It is required to limit or eliminate the source pollution from cleaning chemicals, the use of carpet which traps dust, by replacing with } \\
\text { low or no volatile organic compound paints, stains, sealers, and adhesives to improve indoor air quality. }\end{array}$ & {$[17,79]$} \\
\hline & Mechanical ventilation & $\begin{array}{l}\text { Mechanical ventilation is the intentional fan-driven flow of outdoor air into a building. Its systems may include supply fans (which } \\
\text { push outdoor air into a building), exhaust fans (which draw air out of the building and thereby cause equal ventilation flow into a } \\
\text { building), or a combination of both. }\end{array}$ & {$[103,104]$} \\
\hline & Air purifying plants & $\begin{array}{l}\text { The selection of plants to purifying the air is also important. Those plants play a role in purifying the air sustainably by filtering out } \\
\text { toxins, pollutants, and carbon dioxide and replacing them with life-sustaining oxygen. }\end{array}$ & {$[105,106]$} \\
\hline & Energy-efficient devices & $\begin{array}{l}\text { It is important for the construction project to use appliances that consume less energy than the conventional choices. For example, } \\
\text { the project encourages the use of more efficient electrical appliances and devices. }\end{array}$ & {$[107,108]$} \\
\hline & Natural lighting use & $\begin{array}{l}\text { Promoting the installation of windows or light shelves that allow natural light to come into the building is also a very important } \\
\text { aspect of sustainable buildings. This situation will help reduce the energy consumption of electrical devices, such as light bulbs, } \\
\text { LEDs (light-emitting diodes), and lamps. }\end{array}$ & [109] \\
\hline & Lighting control system & $\begin{array}{l}\text { The lighting control system is a system that regulates the operation of lighting utilities in the building and good for a sustainable } \\
\text { building. For example, an automated on/off light will help reduce the overall energy consumption as it will be turned on } \\
\text { automatically at a certain time and place. }\end{array}$ & [109] \\
\hline & Efficient lighting equipment & $\begin{array}{l}\text { Efficient lighting equipment is also an important aspect of a sustainable building. It is very important because the building uses } \\
\text { sustainable lighting equipment will be energy efficient. For example, choosing LED lights over incandescent lights. }\end{array}$ & [107] \\
\hline
\end{tabular}


Lighting from living trees

Living trees can generate weak sources of electricity; thus, buildings can utilize the electrical energy from trees to operate lighting systems in some areas such as parking lots that consume less energy. One of those living trees, gliricidia sepium, is existing in [110,111] Cambodia and suitable for this condition.

Fiberglass loose fill insulation

It is a composition of $40-60 \%$ recycled glass, thus, it can be considered as a green material. It is used for insulating finished areas, or irregular shape areas. With good insulation, the building will consume less energy.

Its composition is made out of mostly recycled materials (up 82-85\%) whose main component is recycled paper. It can also be implemented with loose-fill insulation technique.

Cellulose insulation materials

This material and technique is another solution for sustainability of the building, since it is made from recycled denim and cotton fiber. Therefore, it can keep the wall slumping and energy efficient.

Green Insulation

Cotton batt and loose fill insulation

Systems

Air infiltration

Air infiltration happens due to the unawareness of air (heat) leaking into the building. Some mitigations are seal plate gaskets, tape, house wraps, foams, and many more, to seal the gap that the air leaks into.

Drainage planes This aspect is about making sure there's no leakage of moisture or water into the building via cavities (windows, doors, or many more) by providing wraps. Therefore, the building is more comfortable and efficient.

This system reduces the energy transmitted from sunlight into the building, thus, reducing the need for air-conditioning. There are

$\begin{array}{ll}\text { Solar radiation control systems } & \begin{array}{l}\text { This system reduces the energy transmitted from sunlight into the building, thus, reducing the need for air-conditioning. There are } \\ \text { three types of systems, static solar protection, static and dynamic shading, and dynamic glazing systems. }\end{array}\end{array}$

On-demand tankless or This system will guarantee that hot water never runs out. Hot water can be produced instantaneously and this also mitigates the Instantaneous standby heat loss of conventional water heat tanks.

Heat-pump water heaters Heat is transferred into the water and is kept at almost the same temperature in an insulated tank. In addition, it is more efficient than other water heaters in which its energy factor can reach up to 2.0 .

This radiant heating machine does not follow the law of air convection, but rather, it radiates heat directly to a position. It reduces

$\begin{array}{ll}\text { Comfort cove radiant heat } & \begin{array}{l}\text { energy consumption compared to conventional heaters. Moreover, it is not harmful and does not reduce the humidity of the indoor } \\ \text { environment. }\end{array}\end{array}$

$\begin{array}{ll}\text { Comfort cove radiant heat } & \begin{array}{l}\text { energy consumption compared to conventional heaters. Moreover, it is not harmful and does not reduce the humidity of the indoor } \\ \text { environment. }\end{array}\end{array}$ This water/air heating system uses earth energy or heat to provide the need for hot water, which is also sustainable. It can be done by either closed or open loop operation.

Green Plumbing

Geothermal heat pumps

A type of heat exchanger that captures heat waste from heat-generating sources such as air-conditioners and refrigerators. This heat waste can be captured and the energy can be transferred to heat up water.

Desuperheaters

Usage of cross-linked PEX pipe is a cross-linked polyethylene pipe that becomes a sustainable solution to the plumbing system due to its durability and polyethylene pipe economicality under the LCA (Life-cycle assessment).

Water efficient landscaping

Landscaping irrigation is the application of water to land areas in a systematic manner to meet the water requirements of decorative and landscape plants. Low-volume irrigation, flood irrigation, and sprinkler irrigation are all used in landscape irrigation.

Innovative wastewater An efficient sustainable design focuses on lowering wastewater generation within a facility while enhancing aquifer recharge in the technologies surrounding area. It can be used to improve the sustainability of the building and its surrounding. 
Building water-use reduction

Commissioning

Indoor environmental quality

Well-designed toilet

Wind

Hydroelectric

Solar water heaters

Renewable Energy

Solar photovoltaic panels
Water efficiency can be improved in a facility in two ways: by the design and installation of high-efficiency water consuming devices and through educating the building's occupants.

This idea is utilized to ensure that building systems are built and installed according to the owner's intent, and that the owner has received adequate training on how to operate and maintain each commissioned system.

A sustainable plumbing design will call for the use of systems that reduce or eliminate the use of traditional construction processes like welding, brazing, soldering, and gluing.

Toilet plays a very important role in the construction project; therefore, a well-designed one can reinforce the sustainability indicator of the building by reducing the materials used in the toilet and also the energy and water consumption.

Wind energy is a type of renewable energy that converts the wind energy into usable types of energy. Wind turbines are the main sources of wind energy in many developed countries, but there are also other sources as well.

Hydroelectric or hydropower energy is also another solution. There are also some side-effects toward the ecosystem for constructing the hydropower dam, but it is more sustainable than oil and gas-based energy for residential purposes.

Solar water heaters turn sunlight into energy to heat the clean water for the building. It comes with two types passive, which uses convection of water to transfer heat and active heater, which forces convection to transfer heat.

This is another form of solar absorbing device (in Tube form) that has lower heat loss compared to flat-plate collectors (FPC). It is

Evacuated tube solar collectors less dependent on climate conditions. A study has shown its better efficiency in the performance of water heating compared to [143,144] normal FPC.

\begin{tabular}{|c|c|c|c|}
\hline & Solar photovoltaic panels & $\begin{array}{l}\text { Photovoltaic or PV panels function as a converter from sunlight to usable form of energy (thermal and electrical). PV panels can be } \\
\text { installed on the exterior of a building; for example, used as lighting on the outside or the surrounding campus. }\end{array}$ & [145-147] \\
\hline \multirow{6}{*}{ Water Conservation } & Indoor water usage & $\begin{array}{l}\text { Indoor water usage can be reduced by replacing some parts of the building with water efficient components. It will further reduce } \\
\text { the water usage and waste water; therefore, no additional water is drawn from resources. }\end{array}$ & {$[126,148]$} \\
\hline & Pressure reduction & $\begin{array}{l}\text { Because flow rate is related to pressure, the maximum water flow from a fixture operating on a fixed setting can be reduced if the } \\
\text { water pressure is reduced. Therefore, water can be conserved by lowering the water pressure. }\end{array}$ & [3] \\
\hline & Rain water harvesting system & $\begin{array}{l}\text { This system collects the rainwater and converts it to usable water without leaving it running off. There are three stages of this system } \\
\text { which are Collection, Distribution, and Storage stages. }\end{array}$ & {$[126,147]$} \\
\hline & Catchment area & $\begin{array}{l}\text { Housing shape and form can have various impacts on catchment areas which introduce roof catchment areas, it will affect the amount } \\
\text { of rainwater harvested and can also be different. }\end{array}$ & {$[149,150]$} \\
\hline & Precipitation rate & $\begin{array}{l}\text { The weather condition which the buildings situated in also influence the amount of rainwater harvested annually. Therefore, } \\
\text { buildings need to be evaluated on rainwater harvesting and water conservation before the construction starts. }\end{array}$ & {$[149,150]$} \\
\hline & Greywater reuse system & $\begin{array}{l}\text { Greywater sources are from bathrooms, wash basins, clothes washing, sinks, and other sources that contain low organic matter. This } \\
\text { type of water can be recycled (treated with disinfection) and used for various purposes. }\end{array}$ & [151-153] \\
\hline
\end{tabular}




\begin{tabular}{|c|c|c|c|}
\hline & Low utility bills & $\begin{array}{l}\text { The passive rainwater harvesting was built from the roof top and required no pump for delivering water as an additional source of } \\
\text { energy. The results of economic analysis showed this system saves tons of water per year. }\end{array}$ & [154] \\
\hline & Landscape water usage & $\begin{array}{l}\text { Water cannot flow to waste in sustainable building, therefore, landscape water usage on plants and species also can save water from } \\
\text { going to waste directly. It acts as fertilizers to give nutrients to the greenery and vegetation. }\end{array}$ & [17] \\
\hline & Water conservation index & $\begin{array}{l}\text { The water conservation index is the ratio of actual water usage in a building to average water consumption in the general population. } \\
\text { It can be used to assess the water consumption and reduction of the building. }\end{array}$ & [126] \\
\hline \multirow{7}{*}{$\begin{array}{l}\text { Green Floor } \\
\text { Framing Systems }\end{array}$} & Engineered structural lumber & $\begin{array}{l}\text { Structural composite lumber (SCL) refers to a group of engineered wood products used in structural applications. Good wood with } \\
\text { enough strength for the flooring system is a limited resource, so it is important to use the alternatives. }\end{array}$ & [155] \\
\hline & Construction materials for flooring & $\begin{array}{l}\text { The direct reduction of embodied energy is to increase the number of columns which reduce spans of beams and floors. Thus, } \\
\text { reducing the thickness of the floor which lowers the construction materials, and it is sustainable for the buildings. }\end{array}$ & {$[156,157]$} \\
\hline & One-way floor slab & $\begin{array}{l}\text { As floor is a structural component that consumes most of construction materials, it also poses significant embodied } \mathrm{CO} 2 \text { due to its } \\
\text { manufacturing process. One-way slabs allow designers to achieve a portion of embodied CO2 reduction. }\end{array}$ & [158] \\
\hline & Timber concrete composite & $\begin{array}{l}\text { Implementation of sustainable design without sacrificing the structural integrity of a building is important. The timber concrete } \\
\text { composite (TCC) offers superior sustainability and quick installation compared to other composite floors. }\end{array}$ & [159-161] \\
\hline & Timber steel composite & $\begin{array}{l}\text { The combination of cold-form steel and cross-laminated timber possess lightweight and relatively higher strength characteristics. A } \\
\text { study found that it satisfied structural performance and construction sustainability. }\end{array}$ & {$[162,163]$} \\
\hline & Precast concrete slab & $\begin{array}{l}\text { Precast concrete offers a wide range of benefits recognized by LEED which require minimum energy and increase the life span of } \\
\text { buildings. It is durable and requires low-maintenance and no construction waste is generated in the field. }\end{array}$ & {$[164,165]$} \\
\hline & Flat plate floor system & $\begin{array}{l}\text { Flat plate floor systems are considered as time-saving construction that are often used in residential buildings and also reduce the } \\
\text { floor height. Additionally, it also contributes to the largest influence on determining greenhouse gas emissions. }\end{array}$ & {$[166,167]$} \\
\hline \multirow{6}{*}{ Green Wall Systems } & Advanced framing & $\begin{array}{l}\text { The framing system is cost effective, sustainable, and energy efficient. It is less expensive than conventional framing, optimizes } \\
\text { material usage, reduces construction wastes, and has many more positive environmental impacts. }\end{array}$ & {$[17,168]$} \\
\hline & Panelized homes & $\begin{array}{l}\text { It offers several environmentally sustainable practices, such as foreseeable environmental control, mass manufacturing and materials } \\
\text { production which results in efficient energy and resources consumption. }\end{array}$ & [169] \\
\hline & Outdoor green wall & $\begin{array}{l}\text { Are mostly made up of visual components. Although they can save money by lowering general temperatures, capturing rainwater, } \\
\text { or insulating buildings, they are primarily utilized to provide greenery to the urban scene. }\end{array}$ & [170] \\
\hline & Indoor green wall & $\begin{array}{l}\text { They have greater size restrictions because they must fit within the spaces, they are in. As a result of this restriction, they are } \\
\text { frequently easier to maintain and more sustainable for the building and comfortable for the occupants. }\end{array}$ & {$[170,171]$} \\
\hline & Open wall & $\begin{array}{l}\text { The minimalism practice in the wall system of the building also pushed the sustainable indicator of the building due to its reduction } \\
\text { in energy consumption, material usage, and environmental footprint of the materials. }\end{array}$ & [172] \\
\hline & Structural insulated panels walls & $\begin{array}{l}\text { Structural Insulated Panels as closed walls is a sustainable solution for the construction project due to its high insulation thermal } \\
\text { performance, which is well-known in cold countries. }\end{array}$ & [163] \\
\hline
\end{tabular}




\begin{tabular}{|c|c|c|c|}
\hline & Planter tiles & $\begin{array}{l}\text { This is also known as a green wall system that is a sustainable solution since it maximizes the functional benefits of the plant } \\
\text { combining it with the building performance. }\end{array}$ & [170] \\
\hline & Reduing UHI effect & $\begin{array}{l}\text { Greenery significantly helps cooling buildings and surrounding areas through the process of shading, reduction in reflected heat, } \\
\text { and evapotranspiration. In addition to this, it also promotes natural air cooling. }\end{array}$ & {$[174,175]$} \\
\hline & Improved exterior air quality & $\begin{array}{l}\text { The increase of air pollution and } \mathrm{CO} 2 \text { emissions footprint lead to an environmental problem and polluting the air. Utilizing the green } \\
\text { facade is capable of capturing airborne pollutants and atmospheric deposition on leaf surfaces. }\end{array}$ & {$[174,176]$} \\
\hline & Aesthetic improvement & $\begin{array}{l}\text { Green walls provide aesthetic improvement and link to improve human health and mental well-being. It also provides a unique } \\
\text { view and attracts people to come around which eventually add up to the property values. }\end{array}$ & {$[174,177]$} \\
\hline & Improved energy efficiency & $\begin{array}{l}\text { It serves as the thermal insulation capacity of the building. However, the saving energy depends on various factors such as } \\
\text { surrounding climate, and density of plant coverage that can impact both cooling and heating. }\end{array}$ & {$[174,178]$} \\
\hline & Building structure protection & $\begin{array}{l}\text { Buildings are exposed to weathering (contraction and expansion) which cause the building materials to erode or decay over time. } \\
\text { With the help of a green facade, the exterior finishes is not prone to critical weathering and is more durable. }\end{array}$ & {$[174,179]$} \\
\hline & Noise reduction & $\begin{array}{l}\text { Noise reduction contributes to the reduction of sound level transmitted through the living wall system. It also varies depending on } \\
\text { the overall area of coverage and materials used as structural components in the living wall system. }\end{array}$ & {$[174,180]$} \\
\hline & Green trim packages & $\begin{array}{l}\text { There are several alternatives for wall trimming that can be more sustainable for the building. For example, the radius wall corner } \\
\text { and the false baseboard reduces the usage of construction materials and trimming materials. Moreover, it also saves time and energy } \\
\text { during the constructing process. }\end{array}$ & {$[17,173]$} \\
\hline \multirow{7}{*}{$\begin{array}{l}\text { Green Exterior } \\
\text { Finish Materials }\end{array}$} & Locally made metal roofing & $\begin{array}{l}\text { This sub-category is similar to the locally available categories in the category of materials resource efficiency and waste management. } \\
\text { Therefore, it is kind of redundant with the sub-category above. }\end{array}$ & {$[17,77]$} \\
\hline & Cementitious siding & $\begin{array}{l}\text { Cementous siding or cement board is considered as an practical and sustainable solution due to its durability and high maintenance } \\
\text { efficiency. Regardless of the performance, it also improves the asthetic of the building architecturally. }\end{array}$ & {$[17,181]$} \\
\hline & Corrugated metal & $\begin{array}{l}\text { Corrugated metal is also a remarkable sustainable solution since metal or steel can be used in a very long period of time and it also } \\
\text { can be recycled and even upcycled which prevent raw materials wastage. }\end{array}$ & {$[182,183]$} \\
\hline & Gypsums separation walls & $\begin{array}{l}\text { In a multi-unit building, provide 2-hour fire protection and noise reduction between surrounding units. These walls are compatible } \\
\text { with conventional floor-to-ceiling height and can be utilized on structures up to four floors. }\end{array}$ & [163] \\
\hline & Common cladding alternative & $\begin{array}{l}\text { Cladding, which is simply the application of one material over another, has become one of the most popular options for upgrading } \\
\text { the exterior of an existing structure. }\end{array}$ & [184] \\
\hline & Insulated wall panels & $\begin{array}{l}\text { It is utilized in floors, walls, and roofs to provide a high-performance material that is exceptionally durable, sustainable, and energy- } \\
\text { efficient. Engineered panels, or SIPs, are used to build walls, ceilings, and floors. }\end{array}$ & {$[185,186]$} \\
\hline & Precast concrete slabs & $\begin{array}{l}\text { This concrete slab is made in a manufacturing facility and delivered to construction sites in portions. A lightweight filler, such as } \\
\text { foam insulation, is frequently encased by the outer layers. }\end{array}$ & {$[187,188]$} \\
\hline
\end{tabular}




\begin{tabular}{|c|c|c|c|}
\hline & Porch and deck flooring & $\begin{array}{l}\text { This material is a composite body material that can perform as well as a good piece of timber in construction projects. Therefore, its } \\
\text { durability and low maintenance needs are the key ideas for sustainable building. }\end{array}$ & {$[17,189]$} \\
\hline & Natural clay plaster & $\begin{array}{l}\text { It is one of the conventional materials that have been used for a very long time, but it is unique since it improves the sustainability } \\
\text { of the building due to low energy consumption for the production and transportation. }\end{array}$ & {$[190,191]$} \\
\hline \multirow{11}{*}{$\begin{array}{l}\text { Green Interior } \\
\text { Finish Materials }\end{array}$} & Wheat board & $\begin{array}{l}\text { Wheatboard, sometimes called Eco-board, is a type of MDF fiberboard that is the next generation. It is entirely harmless to the } \\
\text { environment. Wheatboard is composed entirely of high-quality natural wheat straw rather than wood. }\end{array}$ & {$[17,192]$} \\
\hline & Stone veneers & $\begin{array}{l}\text { Stone veneers are great for producing unique interior design features, such as accent walls. A great usage of natural stone design } \\
\text { that can provide a visual framing for the fireplace and mantel is a stone veneer fireplace. }\end{array}$ & [193] \\
\hline & Recycled metal & $\begin{array}{l}\text { A recycled aluminum chair's gleam not only effectively produces industrial design in your home, but it's also a more environmentally } \\
\text { friendly solution. Plus, it also comes with lower price and similar performances. }\end{array}$ & {$[194,195]$} \\
\hline & Bio-glass & $\begin{array}{l}\text { Although you may not want to sit on a bio-glass chaise, it is an excellent green choice for anything from design to bathroom sinks, } \\
\text { worktops, and flooring. It can be used for decoration in different spots of the building. }\end{array}$ & {$[196,197]$} \\
\hline & Sustainable plywood & $\begin{array}{l}\text { Plywood that is made from sustainable yield forest is also considered as a sustainable solution compared to other materials. This } \\
\text { might not be famous in Cambodia, but it is also one of the sustainable solutions for the building. }\end{array}$ & {$[17,198]$} \\
\hline & Corrugated metal & $\begin{array}{l}\text { Corrugated metal roofing is made out of metal sheets that have been rolled into panels. Screws are then used to secure the panels to } \\
\text { the roof. Corrugated sheet metal is often circular and wavy in form. }\end{array}$ & [183] \\
\hline & Sheet galvanized & $\begin{array}{l}\text { Galvanized steel is ordinary steel that has been zinc-coated to make it corrosion resistant. Regular steel is formed of iron, which rusts } \\
\text { when exposed to moisture, whether from rain or humidity in the air. }\end{array}$ & {$[17,199]$} \\
\hline & Natural clay plaster & $\begin{array}{l}\text { Clay plaster is proven to be an internal humidity regulator due to its natural properties which are vapor permeable properties and } \\
\text { hygroscopic. the energy usage of the building. }\end{array}$ & {$[17,200]$} \\
\hline & Natural fiber wall coverings & $\begin{array}{l}\text { Natural fiber is a widely available and low-cost material. It is considered to be a material, biodegradable, and lightweight material. } \\
\text { Also, natural fiber wall coating is made of natural fibre of cotton, wood, bamboo etc. and is environmental-friendly. }\end{array}$ & {$[201,202]$} \\
\hline & Green cabinets and storage & $\begin{array}{l}\text { Cabinets and storage should be produced from eco-friendly materials as sustainable plywood. Green is both a timeless and soothing } \\
\text { hue that can make any space in your abode feel more inviting. }\end{array}$ & {$[17,203]$} \\
\hline & Open shelving & $\begin{array}{l}\text { Open shelving concept is similar to the open wall system. The concept of minimalism improves the materials efficiency and } \\
\text { sustainability. Open shelving is perhaps one of the most popular kitchen design trends right now. }\end{array}$ & {$[17,204]$} \\
\hline \multirow{3}{*}{$\begin{array}{l}\text { Green Flooring } \\
\quad \text { Systems }\end{array}$} & Recycled carpet & $\begin{array}{l}\text { The carpet that is made from poly-ethylene terephthalate (PET), which are materials that are recycled from plastic waste, is known } \\
\text { as a sustainable material, since it solves the waste problems and creates construction materials. }\end{array}$ & [17] \\
\hline & Carpet squares & $\begin{array}{l}\text { Carpet squares are sustainable materials as long as they do not contact plastic (PVC) that should be avoided. It comes with the long } \\
\text { lifespan and the flexible ability to serve the building purposes with heavy traffic. }\end{array}$ & [17] \\
\hline & Natural linoleum & $\begin{array}{l}\text { Linoleum is a sustainable material that can be recycled after it is worn out. Moreover, the production of these materials does not } \\
\text { require sufficient energy and raw materials. }\end{array}$ & {$[205,206]$} \\
\hline
\end{tabular}




\begin{tabular}{|c|c|c|c|}
\hline & Tile flooring & $\begin{array}{l}\text { Tile installation tool is a device that can assist construction workers or instructors in more quickly and efficiently installing tile. It is } \\
\text { a conventional and also sustainable solution for the construction projects in terms of flooring. }\end{array}$ & [207] \\
\hline & Wool and wool blend carpets & $\begin{array}{l}\text { In terms of comfort and durability, this one is the best one is sustainable flooring. However, it is a little bit expensive compared to } \\
\text { others. Moreover, it is not a famous solution for tropical countries (warm temperature country). }\end{array}$ & {$[208,209]$} \\
\hline & Flooring shape & $\begin{array}{l}\text { Floor shape is an important contribution in green building design which has a significant impact on energy performance and } \\
\text { construction costs. Typical floor optimization also contributes to life-cycle cost and life-cycle of the materials. }\end{array}$ & [210] \\
\hline & Floor green view index & $\begin{array}{l}\text { It is defined as the area of visible green on a particular floor of a city building. This indicator is a very powerful tool for urban design, } \\
\text { landscape architecture, urban green planning and management to develop more green space in the city. }\end{array}$ & [211] \\
\hline Category & Criteria & Description & Ref. \\
\hline \multirow{5}{*}{$\begin{array}{c}\text { Effective } \\
\text { Performance } \\
\text { Management }\end{array}$} & Performance services & $\begin{array}{l}\text { Performance services, such as energy services are those functions performed using energy which are means to obtain or facilitate } \\
\text { desired end services. }\end{array}$ & {$[212,213]$} \\
\hline & Performance efficiency & $\begin{array}{l}\text { Performance efficiency is the comparison between technologies that perform the same functions but different amounts of energy- } \\
\text { saving and efficiency. }\end{array}$ & {$[212,214]$} \\
\hline & Performance metrics & $\begin{array}{l}\text { Performance metrics are defined as figures and data representative of the building performance. The measurements analyze the } \\
\text { impact on water, energy, etc. }\end{array}$ & [215] \\
\hline & Performance upgrades & $\begin{array}{l}\text { It is very important to upgrade the existing building's facilities, including restoring spaces, small rooms, or converting open spaces } \\
\text { in order to improve the building performance. }\end{array}$ & [216] \\
\hline & Performance cycles & $\begin{array}{l}\text { Performance cycles are the implying methods that are capable of green and sustainable performance cycles, energy protection to } \\
\text { increase the quality of indoor air. }\end{array}$ & [217] \\
\hline \multirow{5}{*}{$\begin{array}{c}\text { Effective Monitoring } \\
\text { and Maintenance }\end{array}$} & Post occupancy program & $\begin{array}{l}\text { The post occupancy program is the development and implementation of a post-occupancy tenant education program focused on } \\
\text { evaluating the building. }\end{array}$ & {$[218,219]$} \\
\hline & Smart monitoring & $\begin{array}{l}\text { Installing separate meters for each unit and using habits are reinforced by direct feedback. A smart meter can accurately detect } \\
\text { appliance consumption. }\end{array}$ & [218-220] \\
\hline & Maintenance training & $\begin{array}{l}\text { Training all maintenance personnel on the specific heating and cooling equipment installed in order to maintain optimal } \\
\text { performance. }\end{array}$ & {$[219,220]$} \\
\hline & Effective budgeting & $\begin{array}{l}\text { Effective budgeting is the development of the effective budgeting processes to ensure adequate capital improvement and } \\
\text { maintenance or replacement reserves. }\end{array}$ & [218] \\
\hline & Maintenance schedule & $\begin{array}{l}\text { Following a replacement/maintenance schedule. Don't be tempted to cut corners which may save in the short run but will cost more } \\
\text { in the long run. }\end{array}$ & [218] \\
\hline
\end{tabular}




\begin{tabular}{|c|c|c|c|}
\hline \multirow{4}{*}{$\begin{array}{l}\text { Building Envelope } \\
\text { Integrity }\end{array}$} & $\begin{array}{l}\text { Air-based active building } \\
\text { envelopes }\end{array}$ & $\begin{array}{l}\text { The air-based active building envelope is known as an important installation for air operation that is able to remove a layer of warm } \\
\text { air from the building. }\end{array}$ & [221] \\
\hline & $\begin{array}{l}\text { Water-based active building } \\
\text { envelopes }\end{array}$ & $\begin{array}{l}\text { There are two water-based active building envelope models. One for an active water pipe-embedded wall, and another is a water } \\
\text { evaporative cooling wall. }\end{array}$ & [221] \\
\hline & $\begin{array}{l}\text { Solid-based active building } \\
\text { envelopes }\end{array}$ & $\begin{array}{l}\text { There are three major categories of solid-based active building envelopes, such as photovoltaic (PV), thermoelectric (TE), and PV-TE } \\
\text { wall or roof. }\end{array}$ & [221] \\
\hline & Kinetic active building envelopes & $\begin{array}{l}\text { The kinetic active building envelope is known as adaptive, that can bring appropriate outside air into indoor rooms which can lead } \\
\text { to reduce energy consumption in the building. }\end{array}$ & {$[221]$} \\
\hline \multirow{8}{*}{$\begin{array}{l}\text { Effective HVAC } \\
\text { Management }\end{array}$} & Underfloor air-supply systems & $\begin{array}{l}\text { Technique that organizes the space conditioning inside the building which is considered as a serious alternative to ceiling base air } \\
\text { distribution system. }\end{array}$ & [222] \\
\hline & Desiccant-based cooling systems & $\begin{array}{l}\text { Desiccant-based cooling systems are the heat-driven cooling units that can be utilized as an option in contrast to the ordinary vapor } \\
\text { pressure and absorption cooling system. }\end{array}$ & {$[223]$} \\
\hline & Demand-controlled ventilation & $\begin{array}{l}\text { In HVAC (heating, ventilation, and air conditioning) management, the demand-controlled ventilation uses humidity control which } \\
\text { allows good quality outside air to flow into the inside of the building. }\end{array}$ & {$[224,225]$} \\
\hline & HVAC equipment selection & $\begin{array}{l}\text { Heating and cooling needs, energy efficiency, humidity control, potential for natural ventilation to codes and standards, outdoor air } \\
\text { quantity and quality, indoor air quality, and cost. }\end{array}$ & {$[224,226]$} \\
\hline & Air distribution & $\begin{array}{l}\text { Duct boards and duct liners are widely used in duct systems due to the excellent thermal and control properties. Duct systems pose } \\
\text { no greater risk of mold. }\end{array}$ & [224] \\
\hline & Outdoor air quantity & $\begin{array}{l}\text { Providing HVAC systems and outside air volumes in order to save energy and help control moisture by reducing the quantity of } \\
\text { humid outside air. }\end{array}$ & [224] \\
\hline & HVAC operation and maintenance & $\begin{array}{l}\text { Labeling of HVAC parts is a cheap and powerful technique for aiding the office work and force to appropriately work and keep up } \\
\text { the HVAC frameworks. }\end{array}$ & [224] \\
\hline & Measuring ventilation & $\begin{array}{l}\text { Measuring ventilation is important to determine a particular ventilation rate for instruction, design, or computing purpose using in- } \\
\text { situ measurement techniques. }\end{array}$ & [226] \\
\hline \multirow{4}{*}{$\begin{array}{l}\text { Lighting and Plug } \\
\text { Load Controls }\end{array}$} & Time switch controls & $\begin{array}{l}\text { The time-switch control is using technology that detects human activity or non-business hours which automatically turns off the } \\
\text { light to save energy power. }\end{array}$ & {$[227,228]$} \\
\hline & Occupancy sensor controls & $\begin{array}{l}\text { Occupancy sensor control is using the sensor technology to detect and shut off the circuit when occupants are away from control } \\
\text { space like auto lightning on the stair. }\end{array}$ & {$[227,228]$} \\
\hline & $\begin{array}{l}\text { Electrical wiring for plug load } \\
\text { controls }\end{array}$ & $\begin{array}{l}\text { Hardwired plug load controls require the installation of both controlled and uncontrolled receptacles, which require two sets of } \\
\text { electric circuits to support the two sets of receptacles. }\end{array}$ & [227] \\
\hline & Schedule timer controls & $\begin{array}{l}\text { Optimizing the energy use by analyzing the operation schedule or occupant work like non-business hours, out-of-office hours, and } \\
\text { empty conference rooms. }\end{array}$ & {$[227,228]$} \\
\hline
\end{tabular}




\begin{tabular}{|c|c|c|c|}
\hline \multirow{4}{*}{$\begin{array}{l}\text { Site Management } \\
\text { Overhauling }\end{array}$} & Preventative maintenance & $\begin{array}{l}\text { Method that involved regularly scheduled inspection, repairment, replacement and other tasks that minimize the risks and maximize } \\
\text { the lifespan of the building. }\end{array}$ & [229] \\
\hline & Predictive maintenance & $\begin{array}{l}\text { Determining performance and studying the future plans to improve the maintenance of the asset like a collection of data from sensor } \\
\text { technology, and environmental measurement. }\end{array}$ & [229] \\
\hline & Reliability-centered maintenance & $\begin{array}{l}\text { Methods that focus on reliability and availability with the goals of identifying an optimal maintenance program anchored on many } \\
\text { maintenance strategies. }\end{array}$ & [229] \\
\hline & Condition-based maintenance & $\begin{array}{l}\text { Identifying visual inspection, operational performance, and other tasks which result minimize time spent to maintain a building and } \\
\text { optimize the expansion. }\end{array}$ & [229] \\
\hline \multirow{5}{*}{$\begin{array}{l}\text { Energy and System } \\
\text { Management }\end{array}$} & Smart energy devices & $\begin{array}{l}\text { Using smart energy devices to optimize engery use within the building. For example, a smart plug is a smart home device for } \\
\text { controlling energy use. }\end{array}$ & [230] \\
\hline & Energy performance & $\begin{array}{l}\text { Energy performance under energy and system management criteria is for accurate predictions on the building performance using } \\
\text { all energy quantification methods. }\end{array}$ & [230] \\
\hline & Smart energy monitoring & $\begin{array}{l}\text { Smart energy monitoring under energy and system management criteria is able to recognize the issue such as danger of an outbreak } \\
\text { or a system that fails on functioning. }\end{array}$ & [230] \\
\hline & Heat and power system & $\begin{array}{l}\text { Heat and power system is a system for air conditioning resulting in energy saving, and reduction of CO2 emissions which provide } \\
\text { a good quality to the occupant. }\end{array}$ & [230] \\
\hline & Smart technologies & $\begin{array}{l}\text { It is very significant to use modern and smart technologies to minimize energy and also to provide security for occupants like sensor } \\
\text { lightning, smart cameras, and energy-saving air conditioning. }\end{array}$ & {$[230]$} \\
\hline \multirow{4}{*}{ Energy efficiency } & High-performance windows & Controling the cooling load and reducing the solar heat by adding solar control glass into the area that has a large glass. & [231] \\
\hline & Indoor air quality control & Installing the duct system in order to exhausts stale air from bathroom and kitchen and absorb the fresh air into a building. & [231] \\
\hline & Low air leakage rate & Wrapping a plastic sheet around the edge of the floor system and sealing it to the wall above and foundation below. & [232] \\
\hline & Renewable energy & Solar energy or the particles of sunlight that reach the earth, is a clean, renewable energy source that can be harnessed. & [232] \\
\hline \multirow{6}{*}{$\begin{array}{l}\text { Water Consumption } \\
\text { Management }\end{array}$} & Alternative water sources & Using other alternative sources of water, such as rain and water harvesting, in order to collect water from natural rain. & [233] \\
\hline & Water metering and monitoring & Controlling and monitoring the water consumption inside the building to determine and differentiate the water usage in each month. & [234] \\
\hline & Water efficient equipment & Promoting and using the high-quality equipments to optimize the water distribution within the building and prevent water leakages. & [233] \\
\hline & Standard specifications & Technical specifications for all plumbing products such as pipes, fixture is used to minimize water leakage in the building. & [233] \\
\hline & Non-revenue water reduction & $\begin{array}{l}\text { Recovery of water frameworks including the main pipelines and distribution lines to reach the proficiency in transmission and } \\
\text { prevent water contamination. }\end{array}$ & [233] \\
\hline & Reducing water losses & $\begin{array}{l}\text { It is very important to create guidelines that will help to decrease water losses, for example, washing vehicles, walkways, carports, } \\
\text { and roads with clean water. Rainwater or used water is recommended. }\end{array}$ & [233] \\
\hline
\end{tabular}




\begin{tabular}{|c|c|c|c|}
\hline & Water conserving landscapes & $\begin{array}{l}\text { It is also important to keep executing water-conserving landscapes and harvest the positive output from it and update landscape } \\
\text { principle for proficient landscape water use in the park of the building. }\end{array}$ & [233] \\
\hline & Water harvesting & Technology or method that is used for collecting the water from nature to keep inside the building like rainwater harvesting. & {$[234]$} \\
\hline & Water-waste restriction & $\begin{array}{l}\text { Limiting water usage and apply modern technologies inside the bathroom or kitchen can save more water or reuse the water in an } \\
\text { effective way. }\end{array}$ & [233] \\
\hline & Water restoration & $\begin{array}{l}\text { Methods that can restore the wastewater like take out the trash and prevent it flow into the water or catchment area which cause the } \\
\text { water pollution. }\end{array}$ & [233] \\
\hline & Groundwater management & Identify the groundwater table in order to estimate the next day's water storage and try to keep the groundwater at a constant rate. & [235] \\
\hline \multirow{7}{*}{$\begin{array}{l}\text { Indoor Environment } \\
\text { Controls }\end{array}$} & Lighting quality & $\begin{array}{l}\text { Good lighting quality enhances the productivity of the occupants as well as their visual comfort and improves the environment } \\
\text { inside the building. }\end{array}$ & {$[232,236]$} \\
\hline & Acoustic quality & $\begin{array}{l}\text { Good acoustic quality will reduce the noise level for occupants who reside in different offices. Moreover, it also provides occupants } \\
\text { with more privacy when their noises could not be heard by other people. }\end{array}$ & {$[232,237]$} \\
\hline & Thermal comfort & $\begin{array}{l}\text { Occupants should be able to control the thermal environment around them in order to maintain the productivity and comfortability } \\
\text { of their own. }\end{array}$ & {$[232,238]$} \\
\hline & Air quality control & $\begin{array}{l}\text { Good air quality control within the building will help reduces building sick syndrome and enhances the overall betterment of health } \\
\text { for the occupants. }\end{array}$ & {$[239,240]$} \\
\hline & Airflow analysis & $\begin{array}{l}\text { This criteria is important to analyz the air flow rate through specific ventilation components. For instant, terminal diffuser of an air } \\
\text { conditioning system. }\end{array}$ & {$[241,242]$} \\
\hline & Airborne particles & $\begin{array}{l}\text { Indoor air may contain a variety of contaminants that occur as airborne particles. Measuring the airborne particle technique is for } \\
\text { determining its rate. }\end{array}$ & {$[232,243]$} \\
\hline & Air permeability & Measuring air permeability or leakage rate and physical property of a building that indicate the resistance of its fabric to air flow. & {$[244,240]$} \\
\hline \multirow{3}{*}{$\begin{array}{l}\text { Stormwater } \\
\text { Management }\end{array}$} & Green infrastructure & $\begin{array}{l}\text { Relying on plants, soils, and microbial action of soil organisms to encourage stormwater infiltration and evaporation in order to } \\
\text { reduce the stormwater surrounding the building. }\end{array}$ & [245] \\
\hline & Existing landscapes & Reducing the runoff problem by preserving the natural area or natural vegetation which absorb the flood water around the building. & [245] \\
\hline & Stormwater runoff & $\begin{array}{l}\text { Stormwater runoff is the way that we release the water from the surface near the building into our systems which have pipe systems, } \\
\text { storm drains, and gutters. }\end{array}$ & [245] \\
\hline \multirow{2}{*}{$\begin{array}{l}\text { Solid Waste } \\
\text { Management }\end{array}$} & Waste collection & $\begin{array}{l}\text { Proper waste collection is important for environment quality and public health. Government and private collectors to be paid by } \\
\text { homeowners should work together in order to collect all solid wastes in the local area. }\end{array}$ & {$[246,247]$} \\
\hline & Furnace operation & $\begin{array}{l}\text { The technology for reducing the volume of solid waste by burning it in the proper design inside the furnace under a very careful } \\
\text { condition in order to reduce the amount of } \mathrm{CO} 2 \text { emissions. }\end{array}$ & {$[246,248]$} \\
\hline
\end{tabular}
principle for proficient landscape water use in the park of the building. with more privacy when their noises could not be heard by other people.

Indoor Environment

Airborne particles Indoor air may contain a variety of contaminants that occur as airborne particles. Measuring the airborne particle technique is for determining its rate.

Air permeability Measuring air permeability or leakage rate and physical property of a building that indicate the resistance of its fabric to air flow.

Stormwater Existing landscapes Reducing the runoff problem by preserving the natural area or natural vegetation which absorb the flood water around the building. 


\begin{tabular}{|c|c|c|c|}
\hline & Energy recovery & $\begin{array}{l}\text { Utilizing a refractory-lined furnace coupled to a boiler in order to recover energy from solid wastes and permit the energy substance } \\
\text { of the refuse to be recycled. }\end{array}$ & {$[246,249]$} \\
\hline & Sorting and shredding & $\begin{array}{l}\text { Sorting and shredding are carried out mechanically. The decomposable materials in reject are segregated from glass, metal, and } \\
\text { other inorganic things through arranging and isolating tasks. }\end{array}$ & {$[246,250]$} \\
\hline & Digesting and processing & $\begin{array}{l}\text { Waste is prepared for treating either by the open windrow technique or in an enclosed mechanical facility. Windrows are long, low } \\
\text { mounds of refuse. }\end{array}$ & {$[246,251]$} \\
\hline & Controlled by product & $\begin{array}{l}\text { Organic material and inorganic material must be controlled in the proper way in order to avoid the pollutants and difficulties to } \\
\text { control those wasted. }\end{array}$ & [246] \\
\hline & Solid waste recycling & $\begin{array}{l}\text { One sort of recycling is the recovery and reuse of heat energy, a practice discussed separately in incineration. Composting can be } \\
\text { viewed as a recycling process. }\end{array}$ & {$[252,253]$} \\
\hline Category & Criteria & Description & Ref. \\
\hline \multirow{3}{*}{ Site Remodeling } & Disruption minimization & $\begin{array}{l}\text { The top layer soil is valuable for earth's living resources. During remodeling, the plants and trees should be protected. Plus, keeping } \\
\text { existing soil protected will benefit the landscape design stage. }\end{array}$ & [254] \\
\hline & Construction waste recycling & $\begin{array}{l}\text { Recycling construction and demolition wastes help the reduction of land wastes disposal, transportation cost and can sometimes } \\
\text { generate profit by extracting raw materials from the waste. }\end{array}$ & [255] \\
\hline & Solar access design & $\begin{array}{l}\text { Solar access should be taken into consideration. The optimum solar access can provide the maximum amount of solar power, which } \\
\text { is a sustainable power resource. Designers should design the building to always have optimum solar access at the site. }\end{array}$ & [18] \\
\hline \multirow{4}{*}{$\begin{array}{l}\text { Groundwork } \\
\text { Retrofit }\end{array}$} & Pest controls & $\begin{array}{l}\text { Physical pest control and nontoxic pest control are the options that constructors install to the junction of the foundation slab, wall } \\
\text { framing, and structural wood to prevent the building from pests and protect human health. }\end{array}$ & {$[255,256]$} \\
\hline & Crawl space moisture & $\begin{array}{l}\text { Crawl space is the enclosed or free space that is located beneath the first floor of the building. Generally, it is affected by the moisture } \\
\text { due to rain and broken water pipes. The retrofitting of the crawl space can be done by controlling the moisture. }\end{array}$ & [257] \\
\hline & Admixture in concrete & $\begin{array}{l}\text { Fly Ash is an inexpensive material for mixing with the Portland cement used in concrete. Fly Ash and slag could also increase the } \\
\text { strength and durability of the concrete. }\end{array}$ & [258] \\
\hline & Recycled content aggregate & $\begin{array}{l}\text { Recycled content aggregate is the crushed cement concrete or asphalt pavement from construction debris that is reused in other } \\
\text { building projects. Crushed concrete and debris can be used for backfill and drainage at the foundation's base. }\end{array}$ & [259] \\
\hline \multirow{2}{*}{$\begin{array}{l}\text { Landscape Features } \\
\text { Enhancement }\end{array}$} & Resource efficient landscape & $\begin{array}{l}\text { Resource-efficient landscapes are the landscapes that minimize environmental impacts. They use resources and techniques that are } \\
\text { better suited to the local soils, wildlife, rainfall, and climate. }\end{array}$ & {$[254,259]$} \\
\hline & Fire-safe landscape & $\begin{array}{l}\text { Fire-safe landscaping techniques applied into the landscape in order to prevent building and home from fire. It will reduce the risks } \\
\text { of harm by fire to the building and people in the building. }\end{array}$ & {$[259,260]$} \\
\hline
\end{tabular}




\begin{tabular}{|c|c|c|c|}
\hline & Efficient irrigation system & $\begin{array}{l}\text { The highly-efficient irrigation system uses smart irrigation controller's sensors to control the flow rate of the water. It provides only } \\
\text { the amount of water that the plants needed in order to save the water usage. }\end{array}$ & {$[259,261]$} \\
\hline & Composting topsoil & $\begin{array}{l}\text { The compost can be made from waste material such as vegetables, fruit and leaves. Generally, adding of the compost to soil is to } \\
\text { reduce the soil erosion, provide more nutrition by water retaining and improve the soil condition. }\end{array}$ & {$[262]$} \\
\hline & Recycled landscape materials & $\begin{array}{l}\text { There are many waste materials that can be recycled and used for the designing in the landscape with the plant for these purposes. } \\
\text { Recycled material could be car wheels, pieces of wood etc. }\end{array}$ & [263] \\
\hline & Light pollution reduction & $\begin{array}{l}\text { Light pollution can be defined as the brightening from the exterior system of the building which could have the effects on our } \\
\text { ecosystem such as the night animal. }\end{array}$ & {$[264]$} \\
\hline & Solar lamp & $\begin{array}{l}\text { Solar lamp is a function of low voltage, high efficiency, flexibility and economically. Therefore, the use of solar lamp in the landscape } \\
\text { could save the energy. }\end{array}$ & {$[254]$} \\
\hline & Rainwater collection system & $\begin{array}{l}\text { Rainwater harvesting is a technology that stores and provides water utility, it may be collected from many sources such as roofs, } \\
\text { pavement, hill or land catchment. }\end{array}$ & {$[265]$} \\
\hline & Hydro-zoning & $\begin{array}{l}\text { The technique involves grouping plan by water needs consists of dividing the landscape into low, medium, and high water-use to } \\
\text { prevent overwatering. }\end{array}$ & {$[18]$} \\
\hline \multirow{6}{*}{$\begin{array}{l}\text { Material Efficient } \\
\text { Structural Frame }\end{array}$} & Engineered lumber & $\begin{array}{l}\text { Engineered lumber could reduce demand for large-sized logs and reduce the strain on old-growth trees to be cut down. Engineered } \\
\text { timber could make a more durable and higher quality building. }\end{array}$ & {$[259,266]$} \\
\hline & Steel stud interior frame & $\begin{array}{l}\text { Steel stud is generally lighter than wood, and it's stronger and easier to recycle. In addition, the use of steel studs reduces the need } \\
\text { of wood as interior walls. }\end{array}$ & {$[18,260]$} \\
\hline & Certified harvesting wood & $\begin{array}{l}\text { The timbers which are certified by the Forestry Administration were obtained by harvesting in a sustainable way; therefore, the } \\
\text { precious, old-growth trees could be protected for long-term benefits. }\end{array}$ & {$[18,266]$} \\
\hline & Energy-heel trusses & $\begin{array}{l}\text { This was found to be important when energy heels raise the height of the truss at external wall top plates to enable additional } \\
\text { insulation at the house's perimeter. }\end{array}$ & [267] \\
\hline & Advanced framing techniques & $\begin{array}{l}\text { The advance framing could help to reduce the material cost by reducing the diameter of material and labor cost; therefore, it makes } \\
\text { the more efficient structure. }\end{array}$ & {$[259,268]$} \\
\hline & Garage pollution design & $\begin{array}{l}\text { Pollution from the garage can be carbon monoxide }(\mathrm{CO}) \text {, and carbon dioxide }\left(\mathrm{CO}_{2}\right) \text {. It can be prevented from entering the to the } \\
\text { building by having a proper design, installation, and maintenance of gas appliances. }\end{array}$ & [269] \\
\hline \multirow{3}{*}{$\begin{array}{l}\text { Exterior Finish } \\
\text { Renovation }\end{array}$} & Recycled decking materials & $\begin{array}{l}\text { Plastic lumber and wood lumber are two examples of recycled-content decking materials. These materials have a better durability } \\
\text { than wood and could also be cost saving. }\end{array}$ & {$[259,266]$} \\
\hline & House wrap & $\begin{array}{l}\text { House wrap helps by allowing water vapor to pass through the membrane. The installation of house wrap before the siding } \\
\text { installation could help to minimize the moisture buildup in stud cavities. }\end{array}$ & {$[259,268]$} \\
\hline & Durable siding materials & $\begin{array}{l}\text { Siding materials, generally made of metal, stone, brick stucco, and fiber cement are durable and noncombustible which means that } \\
\text { it could prevent fire. }\end{array}$ & {$[259,260]$} \\
\hline
\end{tabular}




\begin{tabular}{|c|c|c|c|}
\hline & Rain screen wall system & $\begin{array}{l}\text { Rain screen wall system is a system that helps the building from the external moisture penetration. It allows for an air space between } \\
\text { the wall structure, and it protects the home from rain intrusion. }\end{array}$ & [18] \\
\hline \multirow{3}{*}{$\begin{array}{l}\text { Provision of } \\
\text { Insulation }\end{array}$} & Floor insulation & $\begin{array}{l}\text { The floor insulation in the crawl space could protect interior air quality from moisture that can grow in wet crawl areas and improves } \\
\text { comfort by insulating the floor. }\end{array}$ & {$[257,267]$} \\
\hline & Ceiling and wall insulation & $\begin{array}{l}\text { Ceiling and wall insulation is about increased insulation in the walls and ceilings provides more comfort, lowers heating and cooling } \\
\text { costs, and makes the property quieter. }\end{array}$ & {$[18,267]$} \\
\hline & Caulking and weather stripping & $\begin{array}{l}\text { Caulking and weather stripping seals the gaps in the doors and windows, and does allow the unwanted air, pollen, mold, dust, and } \\
\text { contaminants to get in the home. It helps to reduce air filtration, lower energy bills, and increase comfort. }\end{array}$ & [18] \\
\hline \multirow{4}{*}{$\begin{array}{l}\text { Water-efficient } \\
\text { Plumbing System }\end{array}$} & Water heater jacket & $\begin{array}{l}\text { Water heater jacket insulation is an insulated wrapper that is secured around the hot water tank or it is able to preserve the } \\
\text { temperature in the water tank. }\end{array}$ & [260] \\
\hline & High efficiency toilets & $\begin{array}{l}\text { High efficiency toilets (HETs) help to save water usage such as using the dual flush feature. HET allows residents to reduce water } \\
\text { and sewer costs. }\end{array}$ & {$[18,270]$} \\
\hline & $\begin{array}{l}\text { Water-efficient faucets and } \\
\text { showerheads }\end{array}$ & $\begin{array}{l}\text { Showerhead water filters help to reduce chemicals and particulates from the water supply. Water efficient showerheads cand save } \\
\text { the amount of the water used by optimizing the flow of water. }\end{array}$ & [18] \\
\hline & Efficient hot water distribution & $\begin{array}{l}\text { By insulating the entire length of hot water piping, energy loss can be reduced. Another way is to insulate all accessible hot water } \\
\text { pipes inside the buildings. }\end{array}$ & [18] \\
\hline \multirow{7}{*}{$\begin{array}{l}\text { Energy-efficient } \\
\text { HVAC system }\end{array}$} & Kitchen hood venting & $\begin{array}{l}\text { Kitchen hood venting is the machine to extract the smoke and smell coming from the cooking by improving indoor air quality, } \\
\text { preventing overheating, and excess moisture. }\end{array}$ & {$[18,271]$} \\
\hline & Hydronic heating & $\begin{array}{l}\text { Hot water is forced through vents in various areas or zones throughout the building by hydronic heating. It's most commonly used } \\
\text { as baseboards or in floors. }\end{array}$ & [271] \\
\hline & High-efficient HVAC filter & $\begin{array}{l}\text { HVAC stands for heating, ventilation, and air conditioning systems. Dust and particulates are removed from the air by high } \\
\text { performance filters. }\end{array}$ & {$[259,260]$} \\
\hline & Installing whole house fan & $\begin{array}{l}\text { Through exhausting warm indoor air and taking in vast amounts of fresh, cold outside air at night, whole house fans can cool a } \\
\text { house without using the air conditioner. }\end{array}$ & [267] \\
\hline & Fresh air mechanical ventilation & $\begin{array}{l}\text { The system provides the ventilation by allowing the air to enter the house and exchanges with the living area. Then attic ventilation } \\
\text { systems improve convenience, lower air conditioning costs, and eliminate issues. }\end{array}$ & {$[259,260]$} \\
\hline & Carbon monoxide alarms & $\begin{array}{l}\text { When the poisonous gas or carbon monoxide (CO) occurs inside the house, alarm from the system will provide a loud alert to signal } \\
\text { the owner to get out of the house. }\end{array}$ & [272] \\
\hline & Good location of ductwork & $\begin{array}{l}\text { This is important to install the effective ductwork at a good location in the building significantly reduce the energy lose and improve } \\
\text { owner comfort. }\end{array}$ & [18] \\
\hline $\begin{array}{l}\text { Renewable Energy } \\
\text { Adoption }\end{array}$ & Solar water heating & $\begin{array}{l}\text { Solar water heating systems use solar panels to collect heat from the sun, and the hot water is stored for use later. The benefit of the } \\
\text { system is the reduce in the use of gas or electricity for water heating. }\end{array}$ & [267] \\
\hline
\end{tabular}




\begin{tabular}{|c|c|c|c|}
\hline & Photovoltaic system & $\begin{array}{l}\text { Running wires from the roof to the electric utility entrance or circuit breaker panel will help save money on photovoltaic panel (PV) } \\
\text { construction in the future. Photovoltaic systems convert solar power to energy. }\end{array}$ & [259] \\
\hline & Wind energy & $\begin{array}{l}\text { Wind energy is the energy created by air in motion. Extracting wind energy is a technique to convert the wind power from the } \\
\text { moving turbine to produce the electricity. }\end{array}$ & [273] \\
\hline & Biomass energy & $\begin{array}{l}\text { Biomass energy is an effective renewable energy source because the energy is obtained by decomposing organic waste, and the waste } \\
\text { would transform into methane gas from a controlled manner, which could provide energy. }\end{array}$ & [270] \\
\hline \multirow{4}{*}{ Tile Resurface } & Renewable flooring materials & $\begin{array}{l}\text { There are two main renewable woods used in flooring material such as bamboo and cork because they are fast in growing and can } \\
\text { be replenished. Importantly, they are durable, hardwood, fire and moisture resistant. }\end{array}$ & [271] \\
\hline & Recycled ceramic tile & $\begin{array}{l}\text { Tiles made from recycled-content materials are extremely durable and perform well since it is very thick, and it could decrease the } \\
\text { quantity of moisture and stains absorbed into the tile and make it more resilient. }\end{array}$ & {$[18,259]$} \\
\hline & Exposed concrete floor & $\begin{array}{l}\text { The floor can be made by polishing the concrete slab surface as flooring finish. It's durable, hard wearing, easy to clean and could } \\
\text { save money from buying tiles. }\end{array}$ & [259] \\
\hline & Thermal mass floors & $\begin{array}{l}\text { It refers to the flooring materials (tile and wood) that improve thermal mass. It could help reduce the energy for heating and cooling, } \\
\text { and keep constant comfortable temperature. }\end{array}$ & [18] \\
\hline \multirow{3}{*}{$\begin{array}{l}\text { Indoor Air Quality } \\
\text { Enhancement }\end{array}$} & Low-VOC products & $\begin{array}{l}\text { The products (such as paint) that have low amount of VOC (volatile organic compound) could avoid the harmful emissions in the } \\
\text { building, reduce potential harmful effects on the health of residents and installers, and therefore improves indoor air quality. }\end{array}$ & {$[18,268]$} \\
\hline & Entryway design & $\begin{array}{l}\text { A proper entryway design could reduce the dust that might be stuck with the shoes from entering the building. Generally, designers } \\
\text { should consider the addition of the storage for placing the shoes before entering the building. }\end{array}$ & [260] \\
\hline & Whole house vacuum & $\begin{array}{l}\text { This is about whole house vacuums that exhaust the dust to the outside rather than collecting them in a bag that may not filter the } \\
\text { dust effectively. }\end{array}$ & [259] \\
\hline \multirow{5}{*}{$\begin{array}{l}\text { Efficient Appliances } \\
\text { and Equipment }\end{array}$} & Energy-efficient dishwasher & $\begin{array}{l}\text { The use of water-efficient dishwashers can save energy. This is because most of the energy consumed by dishwashers is used for } \\
\text { heating the water. }\end{array}$ & [267] \\
\hline & Energy-efficient clothe washer & $\begin{array}{l}\text { It was found that the use of energy star clothes washing machine helps the owner to save time, save energy, cut down water usage } \\
\text { and electric bill. }\end{array}$ & {$[18,259]$} \\
\hline & Energy-efficient refrigerator & $\begin{array}{l}\text { Refrigerators and freezers are the necessary appliances in the building. New appliances are much more energy efficient such as the } \\
\text { energy star refrigerators. }\end{array}$ & {$[18,268]$} \\
\hline & Built-in recycling & $\begin{array}{l}\text { The built-in recycling center in the building provides separated recycling bins and bins for food waste. It provides convenient sorting } \\
\text { and managing of the waste. }\end{array}$ & {$[18,259]$} \\
\hline & Lighting control systems & $\begin{array}{l}\text { Lighting control system could switch lights off in unused areas or when not necessary using the smart sensors. It could save the } \\
\text { electricity by allowing the light to be turned on for less period of time. }\end{array}$ & {$[260,264]$} \\
\hline
\end{tabular}




\section{References}

1. Why the city is usually hotter than the countryside. Available online: https://www.smithsonianmag.com/science-nature/cityhotter-countryside-urban-heat-island-science-180951985/ (accessed on 14 June 2021).

2. De Munck, C.; Pigeon, G.; Masson, V.; Meunier, F.; Bousquet, P.; Tréméac, B.; Merchat, M.; Poeuf, P.; Marchadier, C. How much can air conditioning increase air temperatures for a city like Paris, France? Int. J. Climatol. 2013, 33, $210-227$.

3. Air conditioning raising night-time temperatures in the US. Available online: https://www.theguardian.com/environment/2014/jun/09/air-conditioning-raising-night-time-temperatures-us (accessed on 14 June 2021).

4. Nuruzzaman, M. Urban heat island: causes, effects and mitigation measures: a review. Int. J. Envi. Monit. Anal. 2015, 3, 67-73.

5. Chan, P. Assessing sustainability of the capital and emerging secondary cities of Cambodia based on the 2018 commune database. Data 2020, 5, 79 .

6. National Council for Sustainable Development. Guidelines and Certification for Green Buildings in Cambodia: Terms of Reference (ToR); National Council for Sustainable Development: Phnom Penh, Cambodia, 2019.

7. United Nations Development Programme. Energy Efficiency in Buildings - Accelerating Low-carbon Development in Cambodia: Policy Brief \& In-country Case Studies; United Nations Development Programme: Phnom Penh, Cambodia, 2020.

8. Annual workshop to review NCSD-2020 progress and develop Workplan-2021. Available online: https://ncsd.moe.gov.kh/resources/document/gssds-annual-workshop-2020-Doc (accessed on 17 June 2021).

9. Mattessich, P. W.; Monsey, B. R. Collaboration: What makes it work. A review of research literature on factors influencing successful collaboration; Amherst H. Wilder Foundation: Minnesota, USA, 1992.

10. Snyder, H. Literature review as a research methodology: An overview and guidelines. J. Bus. Res. 2019, 104, 333-339.

11. Chan, P. Child-Friendly Urban Development: Smile Village Community Development Initiative in Phnom Penh. World 2021, 2, 505-520. https://doi.org/10.3390/world2040031

12. Sourani, A.; Sohail, M. The Delphi method: Review and use in construction management research. Int. J. Constr. Education Res. 2015, 11, 54-76.

13. Lucko, G.; Rojas, E.M. Research validation: Challenges and opportunities in the construction domain. J. Constr. Eng. Manag. 2010, 136, 127-135.

14. Bendaña, R.; del Caño, A.; de la Cruz, M.P. Contractor selection: Fuzzy control approach. Can. J. Civ. Eng. 2008, 35, 473-486.

15. Yeung, J.F.Y.; Chan, A.P.C.; Chan, D.W.M. Developing a performance index for relationship-based construction projects in Australia: Delphi study. J. Manag. Eng. 2009, 25, 59-68.

16. Chan, P.; Lee, M.-H. Developing sustainable city indicators for Cambodia through Delphi processes of panel surveys. Sustainability 2019, 11, 3166.

17. Nielson, C.; Wolfe, C.B.; Conine, D. Green Building Guide: Design Techniques, Construction Practices E Materials for Affordable Housing; RCAC Corporate Office: California, USA, 2009; pp. 6-53.

18. Home Remodeling: Green Building Guidelines; Build It Green: California, USA, 2007. Available online: https://www.lakeforestca.gov/DocumentCenter/View/1536/Green-Building-Guidelines-2007-Edition-PDF (accessed on 26 April 2021).

19. Gallagher, L.; Kopainsky, B.; Bassi, A.; Betancourt, A.; Buth, C.; Chan, P.; Costanzo, S.; St. George Freeman, S.; Horm, C.; Khim, S.; et al. Supporting Stakeholders to Anticipate and Respond to Risks in a Mekong River Water-Energy-Food Nexus. Ecol. Soc. 2020, 25(4), 29.

20. Han, S.M.; Lee, M.H. Application of Evaluation Index for Urban Sustainability and Resilience: Focused on the Goal 11 of UN Sustainable Development Goals. J. Korea Re. Est. Man. Re. 2019, 29, 7-27.

21. Alias, A.; Mohd Isa, N.K.; Abdul Samad, Z. Sustainable Building through Project Planning Process. European Journal of Sustainable Development 2014; volume 3, pp. 207-218.

22. Agarwal, R.S.; Kalmar, T. Sustainability in Project Management-Eight Principles in Practice. Master's Thesis, Umeå School of Business and Economics, Umeå, Sweden, September 2015.

23. Glavinich T. E. Contractor's guide to green building construction management, project delivery, documentation, and risk reduction, John Willey, 2008.

24. Emuze, F.; Ntoi, B.K.; Isa, R. Sustainability in the Built Environment: Exploring Barriers in South Africa. SASBE. 2015, 11,19-26.

25. Kibert, C.J. Sustainable Construction: Green Building Design and Delivery, 4th ed.; John Wiley \& Sons, 2016.

26. Naboni, E. Sustainable design teams, methods and tools in international practice. In Detail Green, 2014, pp. 69-73.

27. Rodolfo Valdes. et al. Design charrette: An important Tool for the Development of the Sustainable Construction Projects, 2015.

28. Wang, N., Adeli, H.Sustainable building design, Journal of Civil Engineering and Management 2013; volume 20, pp 1-10.

29. M. Amir A. K., Yasuo. K, Hiroshi. K, Makoto. K, Makoto. M, Effects of convection heat transfer on Sunagoke moss green roof: A laboratory study, Energy and Buildings 2018; volume 158, pp.1417-1428.

30. Henderson, H. In Becoming a Green Building Professional: A Guide to Careers in Sustainable Architecture, Design, Engineering, Development, and Operations, 1st ed; 2012.

31. Wooliams, J. In Planning, Design and Construction Strategies for Green Buildings, Green Building BC, 2001.

32. Akadiri, P.O.; Chinyio, E.A.; Olomolaiye, P.O. Design of A Sustainable Building: A Conceptual Framework for Implementing Sustainability in the Building Sector. Buildings 2012, 2, 126-152.

33. SBI Council. In Green building guidelines: Meeting the demand for low energy, resource efficient homes, 4th ed, Sustainable Buildings Industry Council; 2007.

34. Kibert, C.J. In Sustainable Construction: Green Building Design and Delivery, 3rd ed, Wiley; 2012. 
35. Ching, F.D.K.; Shapiro, I.M. In Green Building Illustrated, 1st ed, Wiley; 2014.

36. Javadian, M. Shamskooshki, H. Momeni, M. Application of Sustainable Urban Development in Environmental Suitability Analysis of Educational Land Use by Using AHP and GIS in Tehran. Procedia Engineering. 2011; Volume 21, pp 72-80.

37. Darus, Z.M.; Hashim, N.A.; Salleh, E.; Haw, L.C.; Rashid, A.K.A.; Manan, S.N.A. Development of Rating System for Sustainable Building in Malaysia. WSEAS Transactions on Environment and Development 2009, 5, 260-272.

38. Holland, L. Diversity and connections in community gardens: A contribution to local sustainability. Local Environment 2004, 9, 285-305.

39. Ye, L; Cheng, Z; Wang, Q; Lin, H; Lin, C; Liu, B. Developments of Green Building Standards in China. Renewable Energy 2015, vol. 73, pp. 115-122.

40. Wu, J. Landscape Ecology. In Ecological Systems; Leemans, R., Eds.; Springer, New York, USA, 2013; Volume 11, pp. 179-200.

41. Manzini, E. Strategic design for sustainability: towards a new mix of products and services. Proceedings First International Symposium on Environmentally Conscious Design and Inverse Manufacturing, 1999, 434-437.

42. Huo, X.; Yu, A; T. W.; Wu, Z. A comparative analysis of site planning and design among green building rating tools. J. Clean. Prod. 2017, 147, 352-359.

43. Global Green USA. In Blueprint for Greening Affordable Housing; Island Press, 2017.

44. Sustainable Micro Irrigation: Principles and Practices, 1st ed.; Megh, R.G.; Apple Academic Press, 2014.

45. Liverman. D. M. In Global Sustainability: A Noble Cause, 1st ed, Cambridge University Press; 2010.

46. Viñas, S.M. Contemporary theory of conservation. Studies in Conservation 2002, 7, 25-34.

47. Ian, C. Consequences of a Food Security Strategy for Economic Welfare, Income Distribution and Land Degradation: The Philippine Case. World Development 2000, 28, 111-128.

48. Chan, P. The Development and Prioritization of Consensus Sustainable City Indicators for Cambodia. Ph.D. Thesis, Hanyang University, Seoul, Korea, August 2020.

49. Sun, C.-Y.; Chen, Y.-G.; Wang, R.-J.; Lo, S.-C.; Yau, J.-T.; Wu, Y.-W. Construction Cost of Green Building Certified Residence: A Case Study in Taiwan. Sustainability 2019, 11, 2195.

50. Jia, X; Klemeš, J.J; Varbanov, P.S; Alwi, S.R.W. Analyzing the Energy Consumption, GHG Emission, and Cost of Seawater Desalination in China. Energies 2019.

51. Kubba, S. Handbook of Green Building Design and Construction: LEED, BREEAM, and Green Globes. Butterworth-Heinemann, 2017.

52. RSMeans. In Green Building: Project Planning \& Cost Estimating, 3rd ed, Wiley; 2011.

53. Zul-Atfi, I. Planning the maintenance of green building materials for sustainable development: a building information modelling approach. Journal of Financial Management of Property and Construction 2021, 6, 141-157.

54. Wang, W.; Rivard, H.; Zmeureanu, R. Floor shape optimization for green building design. Advanced Engineering Informatics 2006, 20, 363-378.

55. Belniak, S.; Leśniak, A.; Plebankiewicz, E.; Zima, K. The influence of the building shape on the costs of its construction. Journal of Financial Management of Property and Construction 2013, 18, 90-102.

56. Alison, L.; Jeff, H.; Jim B.; Kathryn F.; In innovations in design and construction opportunities for the wood industry; Dovetail Partners, Inc, 2006.

57. Höjer, M.; Mjörnell, K. Measures and Steps for More Efficient Use of Buildings. Sustainability 2018, 10, 1949.

58. Etheridge, D. Natural Ventilation of Buildings: Theory, Measurement and Design (1st ed.). Wiley. (2011).

59. Bonino S. Carbon Dioxide Detection and Indoor Air Quality Control. Occupational Health \& Safety (Waco, Tex.). 2016 Apr; 85(4), 46-48.

60. Juan, Y.K.; Chen, Y.; Lin, J.M. Greywater Reuse System Design and Economic Analysis for Residential Buildings in Taiwan. Water 2016, 8, 546.

61. Spiegel, R.; Meadows, D. In Green Building Materials: A Guide to Product Selection and Specification: A Guide to Product Selection and Specification, 3rd ed.; Wiley, 2010.

62. Lutz J. D.; Klein G.; Springer, D.; Howard, B.D. Residential Hot Water Distribution Systems: Roundtable Session. 2002. Online: https://www.eceee.org/library/conference_proceedings/ACEEE_buildings/2002/Panel_1/p1_11/(accessed on 20 June 2020).

63. Hossain, S.S.; Mathur, L.; Majhi, M.R.; Roy, P.K. Manufacturing of green building brick: recycling of waste for construction purpose. Journal of Material Cycles and Waste Management 2019, 21, 281-292.

64. Aghdam, K.A.; Rad, A.F.; Shakeri, H.; Sardroud, J.M.; Approaching Green Buildings Using Eco-Efficient Construction Materials: A Review of the state-of-the-art. KICEM Journal of Construction Engineering and Project Management 2018, 8, 1-23

65. Stapelberg, R. F. Availability and Maintainability in Engineering Design. In Handbook of Reliability, Availability, Maintainability and Safety in Engineering Design. Springer, London 2009.

66. Chan, P. Cambodian Green Economy. 2019. Available online: https://www.semanticscholar.org/paper/Cambodian-GreenEconomy-Chan/2b3a788abc17041dea4a729ed4f3b3e720c1856b (accessed on 20 June 2020).

67. Bao, Z.; Lu, W.; Chi, B.; Hao, J. Construction waste management performance in green building: Contextualizing LEED in China. Detritus 2020, 1-10

68. Zabihi, H.; Mirsaeedie, L. Towards Green Building: Sustainability Approach in Building Industrialization. International Journal of Architecture and Urban Development 2013, 3, 49-56.

69. Nengmou WANG, Hojjat ADELI. (2014). Sustainable Building Design. Journal of civil engineering and management. Vol 20(1): 1-10.doi:10.3846/13923730.2013.871330 
70. Wang, N.; Adeli, H. 2013. Sustainable building design, Journal of Civil Engineering and Management 20(1): 1-10. http://dx.doi.org/10.3846/13923730.2013.871330

71. Dwaikat, L.; Ali, K. (2018). Green Buildings Life Cycle Cost Analysis and Life Cycle Budget Development: Practical Applications. Journal of Building Engineering, 18, 303-311. doi:10.1016/j.jobe.2018.03.015

72. Kassim, Reshma; Santhi, M.Helen. (2016). Basic studies on embodied energy in construction materials. International Journal of Earth Sciences and Engineering. 9. 2452-2456

73. Lee, B., Trcka, M., Hensen, J. (2010). Embodied energy of building materials and green building rating systems - A case study for industrial halls. Sustainable Cities and Society, 1. doi:10.1016/j.scs.2011.02.002

74. Lee, Bruno; Trcka, Marija; Hensen, Jan. (2010). Embodied energy of building materials and green building rating systems - A case study for industrial halls. Sustainable Cities and Society. 1. 10.1016/j.scs.2011.02.002.

75. Altın, Müjde. (2016). Green Building Rating Systems in Sustainable Architecture.

76. Mohamed, Mady. (2019). Green Building Rating Systems as Sustainability Assessment Tools: Case Study Analysis. 10.5772/intechopen.87135

77. Usman Aminu Umar, Mohd Faris Khamidi, Hassan Tukur (2012). Sustainable Building Material for Green Building Construction, Conservation and Refurbishing.

78. Morel, J. C., Mesbah, A., Oggero, M., Walker, P. (2001). Building houses with local materials: means to drastically reduce the environmental impact of construction. Building and Environment, 36(10), 1119-1126. https://doi.org/10.1016/s03601323(00)00054-8

79. Sustainable Buildings Industry Council. (2007). Green building guidelines: meeting the demand for low-energy, resource-efficient homes.

80. Tsiotas, Dimitrios; Kungolos, Athanassios; Tsiota, A. (2010). Construction Materials Recycling as means of Sustainable Construction.

81. Kamis, A., Suhairom, N., Jamaluddin, R., Syamwil, R., Ahmad Puad, F. (2018). Environmentally Sustainable Apparel: Recycle, Repairing and Reuse Apparel. The International Journal of Social Sciences and Humanities Invention, 5. doi:10.18535/ijsshi/v5i1.04

82. Nindyati, Ayu. (2014). Green Behavior (Reuse, Reduce, Recycling -3r) At Home and At Workplace. 10.13140/RG.2.1.3229.7365.

83. Samiha, Bouanini. (2013). The Importance of the 3R Principle of Municipal Solid Waste Management for Achieving Sustainable Development. Mediterranean Journal of Social Sciences. 4. 129-135. 10.5901/mjss.2013.v4n3p129.

84. Akdağ, H. C., Beldek, T. (2017). Waste management in green building operations using GSCM. Int. J Sup. Chain. Mgt Vol, 6(3), 174.

85. Haggag, M., Hassan, Ahmed. (2015). Cost-benefit analysis of living wall systems on school building skins in a hot climate. 3-11. 10.2495/ESS140011.

86. Perini, Katia; Rosasco, Paolo. (2013). Cost-benefit analysis for green façades and living wall systems. Building and Environment. 70. 110-121. 10.1016/j.buildenv.2013.08.012.

87. Shah. P., et al. (2004). Sustainable development and concrete technology. International Workshop. Beijin, China

88. Gagan, Arora, Sumit. (2015). Recycled Aggregates: A Sustainable Solution of Construction and Demolished Waste. IOSR Journal of Mechanical and Civil Engineering. 2278-1684.

89. Ravindra K. Dhir, Jorge de Brito, et al. (2019). Sustainable Construction Materials: Recycled Aggregates (Book). A volume in Woodhead Publishing Series in Civil and Structural Engineering.

90. Safiuddin, Md; Alengaram, U.Johnson; Rahman, Moshiur; Salam, Md; Jumaat, Zamin. (2013). Use of recycled concrete aggregate in concrete: A review. Journal of Civil Engineering and Management. 19. 796-810. 10.3846/13923730.2013.799093.

91. Rajagopalan, N., Bilec, M. M., \& Landis, A. E. (2010). Residential life cycle assessment modeling: comparative case study of insulating concrete forms and traditional building materials. Journal of Green Building, 5(3), 95-106.

92. Angelo Massafra et, al. (2020). Wooden Truss Analysis, Preservation Strategies, and Digital Documentation through Parametric 3D Modeling and HBIM Workflow.

93. Pavan Kumar, J. D. (2016). Quantitative Study of Howe Truss (A- Type) and. Vaddeeswaram Guntur : http://www.ijert.org.

94. Mcgraw, Jim; Zofka, Adam; Krivit, Dan; Schroer, Joe; Olson, Roger; Marasteanu, Mihai. (2007). Recycled Asphalt Shingles in Hot Mix Asphalt.

95. Holly Welles. (2019). Why are cool roofs a new trend in eco-friendly design? Biofriendly Planet.

96. Pisello, Anna Laura. (2013). Analysis of a cool roof system for reducing cooling loads and improving cooling system efficiency.

97. Rogers, Judy. (2013). Green, brown or grey: green roofs as 'sustainable' infrastructure. WIT Transactions on Ecology and the Environment. 173. 323-333. 10.2495/SDP130271.

98. Korol, Svetlana; Shushunova, Natalia; Shushunova, Tatiana. (2018). Innovation technologies in Green Roof systems. MATEC Web of Conferences. 193. 04009. 10.1051/matecconf/201819304009.

99. Alassar, Zakaria. (2017). Louver Windows as a Passive Cooling Strategy. 10.13140/RG.2.2.23816.42244.

100. Kouhirostami, Maryam; Kouhirostamkolaei, Mahtab; Sam, Mahya. (2021). Understanding the Importance of Window Design and Natural Ventilation in a Classroom Based on Human Preference. 10.13140/RG.2.2.19996.41601.

101. Louw, Hentie. (1983). The Origin of the Sash-Window. Architectural History. 26. 49. 10.2307/1568434.

102. Kirankumar, Gorantla; Saboor, Shaik; Babu, T.P. (2017). Investigation of Various Low Emissivity Glass Materials for Green Energy Building Construction in Indian Climatic Zones. Materials Today: Proceedings. $4.8052-8058$. 10.1016/j.matpr.2017.07.144. 
103. Peter O. Akadiri, et. al. (2012). Design of A Sustainable Building: A Conceptual Framework for Implementing Sustainability in the Building Sector. Buildings 2012, 2, 126-152; doi:10.3390/buildings2020126.

104. Russell, Marion; Sherman, Max; Rudd, Armin. (2007). Review of Residential Ventilation Technologies. HVAC\&R Research. 13. 325-348. 10.1080/10789669.2007.10390957.

105. Abd Wahab, Izudinshah; Ismail, Lokman. (2012). A Study on Plant Selection for Green Building Design. Journal of Science and Technology. 4. 65-78.

106. Claudio, L. (2011, October 1). Planting Healthier Indoor Air. Retrieved from NCBI: https://www.ncbi.nlm.nih.gov/pmc/articles/PMC3230460/_(accessed on 22 June 2021).

107. Andullah A. Alshorman, M. A. (2017). Green Buildings Analysis for Energy Efficiency Enhancement-Jordanian Concept. International Journal of Emerging Trends in Engineering and Development Issue 7, Vol. 6, 1-9.

108. Dwaikat, L. N.; Ali, K. N. (2016). Green buildings cost premium: A review of empirical evidence. Energy and Buildings, 110, 396-403. doi:10.1016/j.enbuild.2015.11.021

109. Sujit Kumar Patro, G. S. (2016). Sustainable energy efficiency lighting in green buildings: An approach with DC based lighting systems. International Research Journal of Engineering and Technology (IRJET), 33-35.

110. Lee, Ming Foong; Zain, M.N.N.; Lai, Chee sern. (2018). Lighting system design using green energy from living plants. Journal of Physics: Conference Series. 1019. 012019. 10.1088/1742-6596/1019/1/012019.

111. Howe Cheng, Teng; Bc, Kok; Uttraphan, Chessda; Yee, Heong. (2018). A review on energy harvesting potential from living plants: Future energy resource. International Journal of Renewable Energy Research. 8. 2398-2414.

112. Energy.gov. (n.d.). Insulation Materials. Retrieved from Energy Saver: https://www.energy.gov/energysaver/weatherize/insulation/insulation-materials (accessed on 22 June 2021).

113. Energy.gov. (n.d.). Types of Insulation. Retrieved from Energy Saver: https://www.energy.gov/energysaver/types-insulation (accessed on 22 June 2021).

114. Lea, D. (1996, June 24-25). Cellulose: Building Insulation with High Recovered Content, Low Embodied Energy. Gainesville, FL, USA.

115. Bozsaky, David. (2019). Nature-Based Thermal Insulation Materials from Renewable Resources - A State-Of-The-Art Review. Slovak Journal of Civil Engineering. 27. 52-59. 10.2478/sjce-2019-0008.

116. Chadi Younes, C. A. (2012). Air infiltration through building envelopes: A review. Journal of Building Physics, 274.

117. Casini, M. (2015). Smart windows for energy efficiency of buildings. Proc. of the Second Intl. Conf. on Advances In Civil, Structural and Environmental Engineering, 273-280.

118. Building Green, Inc. (2015). Building Green's Guide to Green Plumbing Product. Retrieved from Building Green: https://www.buildinggreen.com/sites/default/files/ebn/EBN_24-9.pdf (accessed on 22 June 2021).

119. Brazeau, Randi; Edwards, Marc. (2013). Water and energy savings from on-demand and hot water recirculating systems. Journal of Green Building. 8. 75-89. 10.3992/jgb.8.1.75.

120. Comfort Cove. (2014). The Efficient Radiant Heating Solution. Retrieved from Comfort Cove: https://www.radiantsystemsinc.com/assets/docs/92849-RadiantSystems\%20Comfort\%20Cove\%20Book.pdf (accessed on 22 June 2021).

121. Žandeckis, Aivars; Klavina, Krista; Dzikevics, Mikelis; Kirsanovs, Vladimirs; Žogla, Gatis. (2015). Solutions for Energy Efficient and Sustainable Heating of Ventilation Air: A Review. Journal of Engineering Science and Technology Review. 8. 98-111. 10.25103/jestr.083.14.

122. Jamil, Rehan; Alhusayni, Abdulrahman. (2020). Economic Comparison of Geothermal Heat Pump System and Conventional Water Heaters for Hot Water Supply in Apartment Buildings.

123. Nimish Dhepe, R. K. (2017). A Review of the Advancements in Geothermal Heating and Cooling Systems. Journal of Alternate Energy Sources and Technologies, 1-4.

124. Asadi, Somayeh; Babaizadeh, Hamed; Foster, Nolan; Broun, Reza. (2016). Environmental and economic life cycle assessment of PEX and copper plumbing systems: A case study. Journal of Cleaner Production. 137. 10.1016/j.jclepro.2016.08.006.

125. M.L. Durand, et al (2007). Contributions of silane cross-linked PEX pipe to chemical/solvent odours in drinking water. Water Science \& Technology 55(5):153-60 DOI:10.2166/wst.2007.174.

126. Oindrila Das, et al (2015). Water Conservation Aspects of Green Buildings. EI of steel plate to create footing in PLAXIS 2D.

127. Rolson St. Hilaire, et al (2008). Efficient Water Use in Residential Urban Landscapes. Hort Science: a publication of the American Society for Horticultural Science 43(7). DOI: 10.21273/HORTSCI.43.7.2081.

128. Derin Orhon, et al (2002). Innovative technologies for wastewater treatment in coastal tourist areas. Water Science \& Technology 46(8):67-74. DOI:10.2166/wst.2002.0147.

129. Jozef Trela, et al (2018). Innovative technologies in municipal wastewater treatment plants in Sweden to improve Baltic Sea water quality. E3S Web of Conferences 45:00113. DOI:10.1051/e3sconf/20184500113.

130. Xhensila Thomollari, et al (2017). Reducing Water Consumption with Sustainable Building Design; A Case Study.

131. Anuradha Waidyasekara, et al (2016, November). Water use efficiency and conservation during construction: drivers, barriers and practices. Built Environment Project and Asset Management 6(5):553-566. DOI:10.1108/BEPAM-09-2015-0052.

132. Kris Lawry, et al. (2013, January). Integrative Approach to the Plant Commissioning Process. Journal of Industrial Engineering 2013(1):1-12. DOI:10.1155/2013/572072.

133. Muhammad Abdul Mujeebu, et al (2019, January). Introductory Chapter: Indoor Environmental Quality. DOI: 10.5772/intechopen.83612. 
134. Alexandros Karapetsis, et al (2016, November). Indoor Environmental Quality and its Impacts on Health - Case Study: School Buildings.

135. Korčulanin, Laura; Barbosa, Carlos; Ferreira, Ana Margarida. (2015). Placing toilets in sustainable design - the need for social and technological innovation.

136. Lertpocasombut, Krittiya; Sirimontree, Sayan; Witchayangkoon, Boonsap. (2016). Green Building Technology for Public Restroom Conceptual Design via SketchUp. Applied Sciences. 7. 119-126.

137. Ahmed, Mahmoud; Abdel Gawad, Ahmed. (2016). Utilization of Wind Energy in Green Buildings.

138. Al-Ghamdi, Sami G.; Bilec, Melissa. (2016). On-Site Renewable Energy and Green Buildings: A System-Level Analysis. Environmental science \& technology. 50. 10.1021/acs.est.5b05382.

139. Ghaffarian Hoseini, A. H. (2013). Sustainable energy performances of green buildings: A review of current theories, implementations and challenges. Renewable and Sustainable Energy Reviews, 7.

140. Kaunda, Chiyembekezo; Kimambo, Cuthbert; Nielsen, Torbjørn. (2012). Hydropower in the Context of Sustainable Energy Supply: A Review of Technologies and Challenges. ISRN Renewable Energy. 2012. 10.5402/2012/730631.

141. Pavlovic, Tomislav; Radosavljevic, Jasmina; Pavlović, Z.T.; Kostic, Ljiljana.T.. (2006). Solar energy and sustainable development. Facta Universitatis -Sseries: Physics, Chemistry and Technology. 4. 10.2298/FUPCT0601113P.

142. Aidah M J Mahdi, K. I. (2018). The performance of an effective solar water heater enhancement based on experimental study. World Wide Journal of Multidisciplinary Research and Development, 51.

143. Ashutosh Sharma, A. G. (2018). Performance Investigation of Evacuated Tube Solar Heating System: A Review. Journal of Alternate Energy Sources and Technologies, 15-16.

144. Gaur, M.; Saxena, Gaurav; Kushwah, Anand; Gupta, Ankur; Pandey, Krishna Dutta; Malvi, Chandra Shekhar. (2017). Recent Development and Applications of Evacuated Tube Solar Collectors.

145. Ding Ma, Y.-b. X. (2013). Solar Energy and Residential Building Integration Technology and Application. International Journal of Clean Coal and Energy, 10.

146. Ravish Kumar Srivastava, A. K. (2017). A Review on Solar Air Heater Technology. International Journal of Mechanical Engineering and Technology, 1122-1128.

147. Ji, S. (2016). Green Building Materials and their common use in everyday life. 18-21.

148. Al-Qawasmi, Jamal; Asif, Muhammad; Abd El Fattah, Ahmed; Babsail, Mohammad. (2019). Water Efficiency and Management in Sustainable Building Rating Systems: Examining Variation in Criteria Usage. Sustainability. 11. 2416. 10.3390/su11082416.

149. Şahin, N. İ., Manioğlu, G. (2019). Water conservation through rainwater harvesting using different building forms in different climatic regions. Sustainable Cities and Society, 44, 367-377. doi: https://doi.org/10.1016/j.scs.2018.10.010

150. Pachpute, J. S., Tumbo, S. D., Sally, H., Mul, M. L. (2009). Sustainability of Rainwater Harvesting Systems in Rural Catchment of Sub-Saharan Africa. Water Resources Management, 23(13), 2815-2839. doi:10.1007/s11269-009-9411-8

151. Latif Shaikh, "Green Building with Rain Water Harvesting Approach", International Journal of Science and Research (IJSR), Volume 7 Issue 12, December 2018, 625 - 62910.1051/matecconf/201820404004.

152. Al-Jayyousi, O. (2003). Greywater reuse: Towards sustainable water management. Desalination, 156, 181-192. doi:10.1016/S00119164(03)00340-0

153. B.M, S.; P.M, P.; S, K. (2016). Greywater Reuse: A Sustainable Solution for Water Crisis in Bengaluru City, Karnataka, India.

154. Kucukkaya, Elif; Keleşoğlu, Alper; Gunaydin, Hira; Kilic, G. Alevay \& Unver, Umit. (2020). Design of a passive rainwater harvesting system with a green building approach. International Journal of Sustainable Energy. $40.4-13$. 10.1080/14786451.2020.1801681.

155. Dickson, Michael; Parker, Dave. (2015). Engineered timber and structural form in sustainable design. Proceedings of the ICE Construction Materials. 168. 1-12. 10.1680/coma.14.00058.

156. Foraboschi, Paolo; Mercanzin, Mattia; Trabucco, Dario. (2014). Sustainable structural design of tall buildings based on embodied energy. Energy and Buildings. 68. 254-269. 10.1016/j.enbuild.2013.09.003.

157. Hugo Hens, et al. (2012, August). Floors. 10.1002/9783433601952.ch7

158. Fernandez-Ceniceros, Julio; Fernandez, Roberto; Fraile-Garcia, E.; Ascacibar, Francisco Javier. (2013). Decision support model for one-way floor slab design: A sustainable approach. Automation in Construction. 35. 10.1016/j.autcon.2013.06.002.

159. Dias, A.; Schänzlin, Jörg; Dietsch, Philipp. (2018). Design of timber-concrete composite structures. 10.2370/9783844061451.

160. Rodrigues, João Nuno; Dias, A.; Providencia, Paulo. (2014). Timber-concrete composite bridges - sustainability assessment.

161. A. M.P.G. Dias, et al (2018, September). Design of timber-concrete composite structure. DOI:10.2370/9783844061451

162. Navaratnam, Satheeskumar; Widdowfield Small, Deighton; Gatheeshgar, Perampalam; Keerthan, Poologanathan; Thamboo, Julian; Higgins, Craig; Mendis, Priyan. (2021). Development of Cross Laminated Timber-Cold-Formed Steel Composite Beam for Floor System to Sustainable Modular Building Construction. Structures. 32. 681-690. 10.1016/j.istruc.2021.03.051.

163. Salah Amer, et al. (2016). In-plane performance of gypsum board partition wall systems subjected to cyclic loadings, Journal of Constructional Steel Research 124(10):23-36

164. Mohammed, Hussam. (2019). Precast Concrete - Sustainability LEED.

165. Stephen James Hicks, et al. (2003). Design of composite beams using precast concrete slabs. DOI:10.13140/RG.2.2.23890.35529

166. Bae, Sang; Choi, Jewoo; Oh, Hyung; An, Jung; Lee, Min; Yun, Da; Kim, Yousok; Park, Hyo. (2020). Influence of changes in design parameters on sustainable design models of flat plate floor systems in residential or mixed-use buildings. Sustainable Cities and Society. 63. 102498. 10.1016/j.scs.2020.102498.

167. M. Ghoreishi, et al. Estimating the response of flat plate concrete slab systems to fire exposure. January, 2010. 
168. Sunday Olasunkanmi Arowolo. (2017, March). Understanding framing theory. DOI:10.13140/RG.2.2.25800.52482

169. Luther, Mark. (2009). Towards prefabricated sustainable housing - an introduction. TEC 28.

170. Manso, Maria; Castro-Gomes, João. (2015). Green wall systems: A review of their characteristics. Renewable and Sustainable Energy Reviews. 41. 863-871. 10.1016/j.rser.2014.07.203.

171. Yusuke Kumakoshi, et al (2020). Standardized Green View Index and Quantification of Different Metrics of Urban Green Vegetation. DOI:10.3390/su12187434Corpus ID: 220935637.

172. Kendall, Stephen. (1999). Open Building: An Approach to Sustainable Architecture. Journal of Urban Technology. $6.1-16$. $10.1080 / 10630739983551$.

173. J McIntosh; C Guthrie. (2008). Structural Insulated Panels: A Sustainable Option for House Construction In New Zealand? Journal for Housing Science. Vol. 32, No. 1 pp. 15-27

174. Sheweka, Samar; Mohamed, N.M. (2012). Green Facades as a New Sustainable Approach Towards Climate Change. Energy Procedia. 18. 507-520. 10.1016/j.egypro.2012.05.062.

175. Vox, Giuliano; Blanco, Ileana; Schettini, Evelia. (2017). Green façades to control wall surface temperature in buildings. Building and Environment. 10.1016/j.buildenv.2017.12.002.

176. Hadba, Lujain; Silva, Ligia; Mendonça, Paulo. (2017). Green Walls an Efficient Solution for Hygrothermal, Noise and Air Pollution Control in the Buildings.

177. Rakhshandehroo, Mehdi; Mohd Yusof, Mohd Johari; Arabi, Band. (2015). Living Wall (Vertical Greening): Benefits and Threats. Applied Mechanics and Materials. 747. 10.4028/www.scientific.net/AMM.747.16.

178. Coma, Julià; Perez, Gabriel; de Gracia, Alvaro; Burés, Silvia; Urrestarazu, Miguel; Cabeza, Luisa F.. (2017). Vertical greenery systems for energy savings in buildings: A comparative study between green walls and green facades. Building and Environment. 111. 10.1016/j.buildenv.2016.11.014.

179. Norbet Gebbeken. Protection of Buildings. (January, 2013).DOI:10.1007/978-3-642-32021-7_8

180. Azkorra, Zaloa; Pérez, Gabriel; Coma, Julià; Cabeza, Luisa F.; Burés, Silvia; Álvaro, Juan E.; Erkoreka, A.; Urrestarazu, Miguel. (2015). Evaluation of green walls as a passive acoustic insulation system for buildings. Applied Acoustics. 89. 46-56. 10.1016/j.apacoust.2014.09.010.

181. Morbi, Alessandro; Cangiano, Stefano; Borgarello, E. (2010). Cement Based Materials for Sustainable Development. 2nd International Conference on Sustainable Construction Materials and Technologies.

182. Hosny, Sally; Gamal Eldin Ibrahim, Mona; Ali, Dr Ahmed. (2016). Steel as a sustainable choice towards the green building concept. 123-134. 10.2495/SDP160111.

183. Creative Building Supply. (2019). Top 8 Benefits of Corrugated Metal Roofing. Retrieved from Creative Building Supply Co.: https://www.cbssheetmetal.com/top-8-benefits-of-corrugated-metal-roofing/ (accessed on 17 June 2021).

184. Samuel Guy-Plourde, et al (2018). Wood Cladding in Non-residential Construction: Overcoming the Barriers to Leverage the Opportunities. Bioresources 13(1):462-476 DOI:10.15376/biores.13.1.462-476.

185. Micheal A. Mullens, et al. (2006). Structural Insulated Panels: Impact on the Residential Construction Process. Journal of Construction Engineering and Management 132(7).

186. Mohamed Elkady, et al (2015). Precast Concrete Corbels for Insulated Wall Panels. Concrete International.

187. Rafał Szydłowski, et al. (2017). New Concept of Semi-precast Concrete Slab on Pre-tensioned Boards. IOP Conference Series Materials Science and Engineering 245(2):022090.

188. Immanuel Johnsamuel. (2012, November), Precast Design. DOI:10.13140/RG.2.2.31903.10405.

189. Mehrinejad Khotbehsara, Elham; Eghbal, Pegah; Nourmusavi Nasab, Sara. (2016). Porch and balcony as sustainable architecture factors in vernacular houses of west of Guilan: Case studies in Khotbehara, Iran. World Rural Observ. 8. 48-56. 10.7537/marswro080316.07.

190. World Green Building Council - "Advancing Net Zero embodied carbon call to action report" (2019).

191. Sustainability Data (2019). Clayworks. EPD https://clay-works.com/wp-content/uploads/2021/04/clayworks_sustainability_data.pdf (accessed on 17 June 2021).

192. Maraveas, Chrysanthos. (2020). Production of Sustainable Construction Materials Using Agro-Wastes. Materials. 13. 10.3390/ma13020262.

193. Monica Mateo-Garcia, et al (2011). Ventilated Stone Veneer: Mechanical Behaviour, Calculation Methodologies, Major Pathologies and Existing Tests. 10.13140/2.1.2251.5840.

194. Bastiaan C. J. Zoeteman, et al (2009). Handling WEEE waste flows: On the effectiveness of producer responsibility in a globalizing world

195. Markus A Reuter. (2021, April). Challenge of Metal Recycling. Project: Metallurgy a key enabler of the circular economy

196. Vdya krishman, et al. (2013). Bioglass: A novel biocompatible innovation. 10.4103/2231-4040.111523.

197. Imran Farooq. (2012, April). Bioactive Glass: A Material for the Future. World Journal of Dentistry 3(2):199-201 DOI:10.5005/jpjournals-10015-1156.

198. Li, Shenghan; Wu, Huanyu; Ding, Zhikun. (2018). Identifying Sustainable Wood Sources for the Construction Industry: A Case Study. Sustainability. 10. 139. 10.3390/su10010139.

199. N. Conl, et al (2009). Study of the mechanical Propertise of the hot dip galvanized steel and galvalume. Journal of the Brazilian Society of Mechanical Sciences and Engineering 31(4). DOI:10.1590/S1678-58782009000400006.

200. Johanna Liblik, A. J. (2016). Performance of Constructions with Clay Plaster and Timber at Elevated Temperatures. SBE16 Tallinn and Helsinki Conference; Build Green and Renovate Deep, 718. 
201. Yashas Gowda Thyavihalli Girijappa, S. M. (2019). Natural Fibers as Sustainable and Renewable Resource for Development of Eco-friendly Composites: A Comprehensive Review. Frontiers in Materials, 1-3.

202. Marco Leite, et al (2018). Natural Fibre Composites and Their Applications: A review. Journal of Composites Science 2(4):66. DOI: $10.3390 /$ jcs2040066.

203. Preeti Thakur, et al (2016). Material balance, proximate and functional analysis of green banana flour prepared by cabinet drying method.

204. N. P. Hoare, et al. Placing Boxes on Shelves: A Case Study. Journal of the Operational Research Society 52(6). DOI: 10.1057/palgrave.jors.2601130.

205. Bastos, Raquel; Silveira, Paulo. (2016). Linoleum As Floor Covering: Characteristics, Application and Maintenance.

206. Marieke Gorree, et al (2002). Environmental Life Cycle Assessment of linoleum. The International Journal of Life Cycle Assessment 7(3):158-166. DOI:10.1007/BF02994050

207. Arihasnida Ariffin, at al (2018). Designing Tile Installation Tool for Floor Finishing Works. Journal of Physics Conference Series 1049(1):012053.

208. Ingham, Peter; McNeil, Steve; Meade, Warren; Sunderland, Matthew. (2016). Wool and Carpets - 6000 Years of Innovation, Quality and Sustainability. Key Engineering Materials. 671. 490. 10.4028/www.scientific.net/KEM.671.490.

209. Steve McNeil. et al (2016). Wool and Carpets- 6000 Years of Innovation, Quality and Sustainability. Key Engineering Materials 671:490. DOI: 10.4028/www.scientific.net/KEM.671.490

210. Wang, W., Rivard, H., Zmeureanu, R. (2006). Floor shape optimization for green building design. Advanced Engineering Informatics, 20(4), 363-378. doi: https://doi.org/10.1016/j.aei.2006.07.001doi:https://doi.org/10.1016/j.scs.2018.10.010

211. Yu, Siyi; Yu, Bailang; Song, Wei; Wu, Bin; Zhou, Jianhua; Huang, Yan; Wu, Jianping; Zhao, Feng; Mao, Weiqing. (2016). Viewbased greenery: A three-dimensional assessment of city buildings' green visibility using Floor Green View Index. Landscape and Urban Planning. 152. 13-26. 10.1016/j.landurbplan.2016.04.004.

212. Tight Construction. Revelle.net. (2021). http://revelle.net/lakeside/lakeside.new/tight.html (accessed on 15 May 2021).

213. Leibowicz, B. D., Lanham, C. M., Brozynski, M. T., Vázquez-Canteli, J. R., Castejón, N. C., Nagy, Z. (2018). Optimal decarbonization pathways for urban residential building energy services. Applied Energy, 230, 1311-1325.

214. Xu, P.; Chan, E. H.-W.; Qian, Q. K. (2011). Success factors of energy performance contracting (EPC) for sustainable building energy efficiency retrofit (BEER) of hotel buildings in China. Energy Policy, 39(11), 7389-7398. doi:10.1016/j.enpol.2011.09.001

215. Fowler, K., Spees, K., Kora, A., Rauch, E., Hathaway, J., Solana, A. (2009). Whole Building Cost and Performance Measurement: Data Collection Protocol. Revision 2.

216. Ryu, H. (2014). Sustainable Building Refurbishment, 29, 101.

217. Environmental sustainability strategies adopted by companies (2021). https://www.fibre2fashion.com/industry-article/7224/environmental-strategies-adopted-by-companies-to-achieve-sustainability (accessed on 15 May 2021).

218. D. Brunelli, I. Minakov, R. Passerone, M. Rossi, "Smart monitoring for sustainable and energy-efficient buildings: A case study," 2015 IEEE Workshop on Environmental, Energy, and Structural Monitoring Systems (EESMS) Proceedings, 2015, pp. 186-191, doi: 10.1109/EESMS.2015.7175875.

219. Riley, M., Kokkarinen, N., Pitt, M. (2010). Assessing post occupancy evaluation in higher education facilities. Journal of Facilities Management, 8(3), 202-213. doi:10.1108/14725961011058839

220. Chui, K.T.; Lytras, M.D.; Visvizi, A. Energy Sustainability in Smart Cities: Artificial Intelligence, Smart Monitoring, and Optimization of Energy Consumption. Energies 2018, 11, 2869.

221. Luo, Y., Zhang, L., Bozlar, M., Liu, Z., Guo, H., Meggers, F. (2019). Active building envelope systems toward renewable and sustainable energy. Renewable and Sustainable Energy Reviews, 104, 470-491. https://doi.org/10.1016/j.rser.2019.01.005

222. Underfloor Technology Overview. Cbe.berkeley.edu. (2021). https://cbe.berkeley.edu/underfloorair/techoverview.htm (accessed on 15 May 2021).

223. Dincer, I., Rosen, M. A. (2007). Exergy analysis of psychrometric processes. exergy, 76-90

224. Heating, Ventilation and Air-Conditioning Systems, Part of Indoor Air Quality Design Tools for Schools; US EPA. (2021). https://www.epa.gov/iaq-schools/heating-ventilation-and-air-conditioning-systems-part-indoor-air-quality-designtools\#airdistribution (accessed on 15 May 2021).

225. Platt, G., Li, J., Li, R., Poulton, G., James, G., Wall, J. (2010). Adaptive HVAC zone modeling for sustainable buildings. Energy and Buildings, 42(4), 412-421. doi:10.1016/j.enbuild.2009.10.009

226. Mumovic, D., Santamouris, M. (2019). In A handbook of sustainable building design and engineering: an integrated approach to energy, health and operational performance (pp. 274-291). essay, Routledge, Taylor \& Francis Group.

227. Zhang, Y.,; Bonneville, C. (2021). Integrated Lighting and Plug Load Controls. https://www.aceee.org/files/proceedings/2012/ data/papers/0193-000089.pdf (accessed on 15 May 2021).

228. Li, D. H. W., Lam, J. C. (2001). Evaluation of lighting performance in office buildings with daylighting controls. Energy and Buildings, 33(8), 793-803. doi:10.1016/s0378-7788(01)00067-6

229. Construction Review Online.com. (2021). https://constructionreviewonline.com/management/construction-site-maintenancestrategies/ (accessed on 15 May 2021).

230. Team, D. (2020). Smart Home Energy Management and Monitoring. Digiteum. https://www.digiteum.com/home-energymonitoring-system/ (accessed on 15 May 2021). 
231. Energy-Efficient New Construction. https://www.dmme.virginia.gov/DE/LinkDocuments/HandbookNewConstruction.pdf (accessed on 15 May 2021).

232. Mumovic, D., Santamouris, M. (2019). In A handbook of sustainable building design and engineering: an integrated approach to energy, health and operational performance (pp. 468-477). Essay, Routledge, Taylor \& Francis Group.

233. Dr. Hazim El-Naser. Water Demand Management Policy, 2016

234. Alyami, S. H., Rezgui, Y. (2012). Sustainable building assessment tool development approach. Sustainable Cities and Society, 5, 52-62. doi:10.1016/j.scs.2012.05.004

235. Water Management Plans and Best Practices at EPA; US EPA. (2021). https://www.epa.gov/greeningepa/water-managementplans-and-best-practices-epa (accessed on 16 May 2021).

236. Leccese, F., Salvadori, G., Rocca, M., Buratti, C., Belloni, E. (2020). A method to assess lighting quality in educational rooms using analytic hierarchy process. Building and Environment, 168, 106501. https://doi.org/10.1016/j.buildenv.2019.106501

237. Lee, Y. S. (2010). Office layout affecting privacy, interaction, and acoustic quality in LEED-certified buildings. Building and Environment, 45(7), 1594-1600. https://doi.org/10.1016/j.buildenv.2010.01.007

238. Taleghani, M., Tenpierik, M., Kurvers, S., van den Dobbelsteen, A. (2013). A review into thermal comfort in buildings. Renewable and Sustainable Energy Reviews, 26, 201-215. https://doi.org/10.1016/j.rser.2013.05.050

239. Huizenga, C, Abbaszadeh, S, Zagreus, Leah, amp; E. Arens. (2006). Air Quality and Thermal Comfort in Office Buildings: Results of a Large Indoor Environmental Quality Survey . Indoor Environmental Quality (IEQ), Vol III(2006), $393-397$. https://doi.org/https://escholarship.org/uc/item/7897g2f8

240. Steinemann, A., Wargocki, P., Rismanchi, B. (2017). Ten questions concerning green buildings and indoor air quality. Building and Environment, 112, 351-358. doi:10.1016/j.buildenv.2016.11.010

241. Fariborz Haghighat; Hongmin Li. (2004). Building airflow movement - validation of three airflow models. Journal of Architectural and Planning Research, 21 (Winter, 2004), 331-349. https://doi.org/http://www.jstor.org/stable/43030710

242. Mannan, M.; Al-Ghamdi, S.G. Indoor Air Quality in Buildings: A Comprehensive Review on the Factors Influencing Air Pollution in Residential and Commercial Structure. Int. J. Environ. Res. Public Health 2021, 18 , 3276. https://doi.org/10.3390/ijerph18063276

243. Kalaiarasan, M., Balasubramanian, R., Cheong, K., Tham, K. (2009). Traffic-generated airborne particles in naturally ventilated multi-storey residential buildings of Singapore: Vertical distribution and potential health risks. Building and Environment, 44(7), 1493-1500. https://doi.org/10.1016/j.buildenv.2008.07.012

244. Jones, B., Das, P., Chalabi, Z., Davies, M., Hamilton, I., Lowe, R., Milner, J., Ridley, I., Shrubsole, C., Wilkinson, P. (2013). The Effect of Party Wall Permeability on Estimations of Infiltration from Air Leakage. International Journal of Ventilation, 12(1), 1730. https://doi.org/10.1080/14733315.2013.11683999

245. Stormwater Management: What Stormwater Management Is and Why It Is Important. Extension Publications.unl.edu. (2021). https://extensionpublications.unl.edu/assets/pdf/g2238.pdf (accessed on 16 May 2021).

246. Solid-waste management - Composting. Encyclopedia Britannica. (2021). https://www.britannica.com/technology/solid-wastemanagement/Composting (accessed on 16 May 2021).

247. Meirinawati, Eva Hany Fanida; Indah Prabawati. (2018). Strategy Management of Hazardous and Toxic Waste Processing by PT Artama Sentosa Indonesia (Study of Transporting and Collecting Hazardous and Toxic Waste). Advances in Social Science, Education and Humanities Research, 226 (1st International Conference on Social Sciences ), 181-186.

248. Zhang, Z., Meng, J., Guo, L., Guo, Z. (2015). Numerical Study of the Gas Distribution in an Oxygen Blast Furnace. Part 1: Model Building and Basic Characteristics. JOM, 67(9), 1936-1944. https://doi.org/10.1007/s11837-015-1529-y

249. Liu, D., Zhao, F. Y., Tang, G. F. (2010). Active low-grade energy recovery potential for building energy conservation. Renewable and Sustainable Energy Reviews, 14(9), 2736-2747. https://doi.org/10.1016/j.rser.2010.06.005

250. Gall, M., Wiener, M., Oliveira, C. C. C. de, W. Lang, R., G. Hansen, E. (2020). Building a circular plastics economy with informal waste pickers: Recyclatequality, business model, and societal impacts. Resources, Conservation \&amp; Recycling, 156(2020). https://doi.org/https://doi.org/10.1016/j.resconrec.2020.104685

251. S S Akimov, V V Grechkina, S V Lebedev. (2021). Building a model for predicting digestive enzymes activity depending on lipid composition of diet. International Conference on World Technological Trends in Agribusiness, 624(2021) 012017).

252. Chan, P.; Lee, M.-H. Prioritizing Sustainable City Indicators for Cambodia. Urban Sci. 2019, 3, 104.

253. W.Y. Ng; C. K. Chaua. (2015). New life of the building materials- recycle, reuse and recovery. The 7th International Conference on Applied Energy - ICAE2015, 75 (2015), 2884-2891.

254. J william Thompson, Kim Sorvig. Sustainable landscape construction a guide to green building outdoors. Island Press; First edition (August 1, 2000)

255. Markandeya Raju Ponnada; Kameswari, P. Construction and Demolition Waste Management - A Review, 2005. https://www.earticle.net/Article/A257077 (accessed on 16 May 2021).

256. Chris A. Geiger; Caroline Cox. Pest Prevention by Design Authoritative Guidelines for Designing Pests Out of Structures. https://sfenvironment.org/article/pest-prevention-by-design-guidelines (accessed on 16 May 2021).

257. Anton TenWolde; Samuel V. Glass. Moisture in Crawl Spaces. https://www.fpl.fs.fed.us/documnts/pdf2013/fpl_2013_tenwolde001.pdf (accessed on 16 May 2021). 
258. Filaj, Esmerald; Bidaj, Altin; Deneko, Enio. Concrete as "Green Building" Material. Albanian Journal of Agricultural Sciences; Tirana 2016, 15, 191-199.

259. Ross Spiegel, Dru Meadows. Green building materials are a guide to protect selection and specification. Wiley; 1 st edition, 1999.

260. Chro Ali Hama Radha. Sustainable renovation residential building in subtropical climate zone, PhD Thesis, University of Pécs, Pécs, Hungary, 2018.

261. Ana Virutube. Benefits of Greenery in Contemporary City. Conf. Ser.: Earth Environ. Sci. 2016, 44, 032020.

262. Adewale M. Taiwo. Composting as a Sustainable Waste Management Technique in Development Countries. J. of Environ. Sci. Tech. 2011, 4, 93-102.

263. Yu-Han Shao; Bin-Yi Liu. The Integration of Reclaimed Materials in Landscape Design, 2016. https://doi.org/10.2991/msmi16.2016.81 (accessed on 16 May 2021).

264. Mohamed Elsahragty; Jin-Lee Kim. Assessment and Strategies to Reduce Light Pollution using Geographic Information Systems, Procedia Engineering 2015, 118479 - 488.

265. Woltersdorf, L.; Liehr, S.; Döll, P. Rainwater Harvesting for Small-Holder Horticulture in Namibia: Design of Garden Variants and Assessment of Climate Change Impacts and Adaptation. Water 2015, 7, 1402-1421.

266. Bob Falk. Wood-framed building deconstruction: a source of lumber for construction? Forest products journal 2002, 52, 8-15.

267. Godfaurd, J., Clements-Croome, D., Jeronimidis, G. Sustainable building solutions: a review of lessons from the natural world. Building and Environment, 2005, 40, 319-328.

268. Hayles, Carolyn S. Environmentally sustainable interior design: A snapshot of current supply of and demand for green, sustainable or fair-trade products for interior design practice. Int. J. Sust. Build. Environ. 2015, 4, 100-108.

269. Bower, J. Attached Garages and Indoor Air Quality, 2001. https://www.aivc.org/sites/default/files/airbase_13672.pdf (accessed on 18 May 2021).

270. Joselin Herbert, G.M., Unni Krishnan, A. Quantifying Environmental Performance of Biomass Energy. Renewable and Sustainable Energy Reviews, 2016, 59, 292-308.

271. Zigenfus, Richard. Element analysis of the green building process, Master's Thesis, Rochester Institute of Technology, New York, USA, November 2008.

272. Neil B. Hampson, Cost effectiveness of residential carbon monoxide alarms. Undersea. Hyperb. Med. $2017,44,393-397$.

273. Cho, K., Jeong, S., Sari, D.P. Harvesting Wind Energy from Aerodynamic Design for Building Integrated Wind Turbines. Inter. J. Tech. 2011 2, 189-198. 